\title{
Defects in Synaptic Plasticity, Reduced NMDA-Receptor Transport, and Instability of Postsynaptic Density Proteins in Mice Lacking Microtubule-Associated Protein 1A
}

\author{
Yosuke Takei, ${ }^{1,2 *}$ Yayoi S. Kikkawa, ${ }^{1,3 *}$ Nafiseh Atapour, ${ }^{4}$-Takao K. Hensch, ${ }^{4,5}$ and $\odot$ Nobutaka Hirokawa ${ }^{1,6}$ \\ ${ }^{1}$ Department of Cell Biology and Anatomy, Graduate School of Medicine, University of Tokyo, Bunkyo-ku, Tokyo 113-0033, Japan, ${ }^{2}$ Department of \\ Anatomy and Neuroscience, Faculty of Medicine, University of Tsukuba, Tsukuba, Ibaraki 305-8575, Japan, ${ }^{3}$ Department of Otolaryngology-Head and Neck \\ Surgery, Graduate School of Medicine, University of Tokyo, Bunkyo-ku, Tokyo 113-0033, Japan, ${ }^{4}$ Laboratory for Neuronal Circuit Development, RIKEN \\ Brain Science Institute, Wako, Saitama 351-0198, Japan, ${ }^{5}$ Department of Molecular and Cellular Biology, Harvard University, Cambridge, Massachusetts \\ 02138, and ${ }^{6}$ Center of Excellence in Genome Medicine Research, King Abdulaziz University, Jeddah 21589, Saudi Arabia
}

Microtubule-associated protein 1A (MAP1A) is a member of the major non-motor microtubule-binding proteins. It has been suggested that MAP1A tethers NMDA receptors (NRs) to the cytoskeleton by binding with proteins postsynaptic density (PSD)-93 and PSD-95, although the function of MAP1A in vivo remains elusive. The present study demonstrates that mouse MAP1A plays an essential role in maintaining synaptic plasticity through an analysis of MAP1A knock-out mice. The mice exhibited learning disabilities, which correlated with decreased long-term potentiation and long-term depression in the hippocampal neurons, as well as a concomitant reduction in the extent of NR-dependent EPSCs. Surface expression of NR2A and NR2B subunits also decreased. Enhanced activity-dependent degradation of PSD-93 and reduced transport of NR2A/2B in dendrites was likely responsible for altered receptor function in neurons lacking MAP1A. These data suggest that tethering of NR2A/2B with the cytoskeleton through MAP1A is fundamental for synaptic function.

Key words: learning and memory; microtubule-associated protein; neuronal plasticity; NMDA receptor; transport

Significance Statement

This work is the first report showing the significance of non-motor microtubule-associated protein in maintaining synaptic plasticity thorough a novel mechanism: anchoring of NMDA receptors to cytoskeleton supports transport of NMDA receptors and stabilizes postsynaptic density scaffolds binding to NMDA receptors. Newly generated mutant mice lacking MAP1A exhibited learning disabilities and reduced synaptic plasticity attributable to disruptions of the anchoring machinery.

\section{Introduction}

Microtubule-associated proteins (MAPs) are filamentous proteins that have been demonstrated to be components of the ex-

Received July 13, 2015; revised Sept. 30, 2015; accepted Oct. 7, 2015.

Author contributions:Y.T., T.K.H., and N.H. designed research; Y.T. and Y.S.K. performed research; N.A. contributed unpublished reagents/analytic tools; Y.T. wrote the paper.

This work was supported by a Grant-in-Aid for Specially Promoted Research to N.H. from the Ministry of Education, Culture, Sports, Science, and Technology of Japan. This research is partially supported by Brain Mapping by Integrated Neurotechnologies for Disease Studies (Brain/MINDS) from Japan Agency for Medical Research and Development. We thank the following Dr. David Bredt (Johnson \& Johnson Research and Development, New Brunswick, NJ) and Susumu Tomita (Yale University, New Haven, (T) for providing the anti-PSD-93 antibody and fulllength PSD-93 CDNA; Dr. Masaki Sakurai (Teikyo University, Tokyo, Japan) for brain crude extract from NR2A knockout mice; Dr. Craig Garner (University of Hamburg, Hamburg, Germany) for providing the map1a cDNA; Dr. Michael Hollman (Ruhr University, Bochum, Germany) and Dr. Shigeo Okabe (University of Tokyo, Tokyo, Japan) for providing the NR1 CDNA; Dr. Andres Barria (University of Washington, Seattle, WA) and Dr. Roberto Malinow (University of California San Diego, San Diego, CA) for providing NR2B/NR2A-EGFP constructs; Dr. Masahiko Watanabe (Hokkaido University, Sapporo, Japan) for providing the anti-PSD-95 and anti-NR2B antibodies; Dr. Tomoaki Shirao (Gunma University, Maebashi, Japan) for providing the anti-synaptophysin antibody; Hiroyuki Katagiri (RIKEN Brain Science tensive cross-bridge structures associated with microtubules (Hirokawa, 1994). Four major neuronal MAPs, namely MAP1A, MAP1B, MAP2, and tau, have been identified as major MAPs based on their abilities to bind microtubule surfaces and stimulate microtubule assembly in vitro (Hirokawa, 1994). Cell biological studies have revealed that tau is essential for axonal growth (Caceres and Kosik, 1990; Takei et al., 2000), MAP2 for dendritic growth (Caceres et al., 1992; Harada et al., 2002), and MAP1B for axonal elongation and neuronal migration (Edelmann et al.,

Institute, Wako, Japan) for suggestions about electrophysiology; and Dr. Chung-Liang Chien (National Taiwan University, Taipei, Taiwan) for providing MAP1A constructs.

${ }^{*}$ Y.T. and Y.S.K. contributed equally to this work.

The authors declare no competing financial interests.

Correspondence should be addressed to Nobutaka Hirokawa, Department of Cell Biology and Anatomy, Graduate School of Medicine, University of Tokyo, Hongo 7-3-1, Bunkyo-ku, Tokyo 113-0033, Japan. E-mail: hirokawa@m.u-tokyo.ac.jp.

DOI:10.1523/JNEUROSCI.2671-15.2015

Copyright $\odot 2015$ the authors $\quad 0270-6474 / 15 / 3515539-16 \$ 15.00 / 0$ 
1996; González-Billault et al., 2000; Meixner et al., 2000; Takei et al., 2000). Among the already identified MAPs, MAP1A is expressed in mature neurons (Schoenfeld et al., 1989; Tucker et al., 1989; Chien et al., 2005). Previous works have reported that MAP1A binds to the proteins postsynaptic density (PSD)-93 and PSD-95, which are members of membrane-associated guanylate kinases (MAGUKs) that scaffold glutamate receptors in synapses (Brenman et al., 1998; Ikeda et al., 2002; Kim and Sheng, 2004). MAP1A is involved in hearing loss of tubby mice (Ikeda et al., 2002) and in activity-driven dendritic remodeling (Szebenyi et al., 2005). However, detailed function of MAP1A in vivo remains essentially unknown. The present study generated MAP1A knock-out mice to investigate the role of MAP1A in vivo. The knock-out mice exhibited learning and memory disturbances, and their neurons revealed defects in synaptic plasticity. Reduced NMDA receptor (NR) transport and activity-dependent PSD-93 instability in the knock-out mice suggest a role for MAP1A in maintaining synaptic plasticity through an interaction with PSD scaffolds and regulation of NR2A/2B transport.

\section{Materials and Methods}

Animals. All experiments using mice were approved by the Graduate School of Medicine, University of Tokyo, and performed under the animal experimentation rules of the university. For behavioral tests, male mice were used. Throughout the other tests and experiments, mice of either sex were killed.

Gene targeting. To disrupt the murine mapla gene, the selection cassette pgkLacZneoSD (Takei et al., 1995) was inserted between the longand short-arm fragments. An A/T pausing signal was added at the $5^{\prime}$ extremity, and a pMC1-DTA cassette was inserted for negative selection. A linearized vector was introduced into the J1 ES cell line (Takei et al., 2000 ) by electroporation, and resistant colonies were selected in the presence of G418. Six homologous recombinant clones were microinjected into C57BL/6 blastocysts, and three independent mouse strains were established. Mouse lines were maintained by repeated backcrossing with C57BL/6 mice in a specific pathogen-free environment. The genetic background of the mice used for experiments was predominantly C57BL/6 (generated by backcrossing more than seven times). ICR mice were used as foster mothers. For genotyping, mouse tails were used for genomic PCR analysis (Takei et al., 2000). The neo transgene was detected as a $200 \mathrm{bp}$ band using the primers 5'-TGGGCACAACAGA CAATCGG-3' and 5'-ACTTCGCCCAATAGCAGCCAG-3'. Intronic sequences from the deleted region of the mapla gene were detected as a $227 \mathrm{bp}$ band using the primers $5^{\prime}$-TGCATCCCTACCCCTAAGGTG-3' and $5^{\prime}$-GACAGGAGAGTGAAGGTGCTTGG-3'. PCR amplification consisted of denaturing at $94^{\circ} \mathrm{C}(30 \mathrm{~s})$, annealing at $65^{\circ} \mathrm{C}(30 \mathrm{~s})$, and extension at $72^{\circ} \mathrm{C}(30 \mathrm{~s})$ for 35 cycles. Southern blot analysis was performed as described previously (Takei et al., 1995).

Behavioral tests. Fear conditioning was performed with slight modifications of a previously described method (Crawley, 2000). mapla $a^{+/+}$ and map $1 a^{-1-}$ mice (16-20 weeks old) were placed in the conditioning chamber for $2 \mathrm{~min}$ and then presented with a $85 \mathrm{~dB}$ tone for $0.5 \mathrm{~min}$ [conditioned stimulus (CS)]. At the end of tone presentation, a footshock [ $2 \mathrm{~s}, 0.8 \mathrm{~mA}$; unconditioned stimulus (US)] was administered to the mice. At $0.5 \mathrm{~min}$ after the footshock, the mice were returned to their housing cages. After $24 \mathrm{~h}$, freezing responses were monitored. For tonedependent fear conditioning, mice were placed in a novel chamber with a context different from the conditioning chamber. Freezing was scored for $3 \mathrm{~min}$ before tone presentation and subsequently for $3 \mathrm{~min}$ in the presence of the tone. For contextual fear conditioning, mice were placed in the conditioning chamber, and freezing was scored for $5 \mathrm{~min}$.

Novel object recognition was performed as described previously (Tang et al., 1999). Mice were handled extensively for $3 \mathrm{~d}$ and then habituated individually to an open-field cage for up to $5 \mathrm{~d}$. During training sessions, two identical objects were placed in the box $20 \mathrm{~cm}$ apart (symmetrically), and the mouse was allowed to freely explore for $5 \mathrm{~min}$. Time spent exploring each object was recorded. In retention tests, the mouse was returned to the same cage, in which one of the familiar objects used during training was replaced by a novel object and allowed to explore for $5 \mathrm{~min}$. Exploratory preference, the ratio of time spent exploring any one of the two objects (training) or the novel one (retention) over the total time spent exploring both objects, was used to measure recognition memory.

Electrophysiology. Hippocampal slices $(350 \mu \mathrm{m})$ were prepared under halothane anesthesia, incubated in oxygenated $\left(95 \% \mathrm{O}_{2} / 5 \% \mathrm{CO}_{2}\right)$ artificial CSF (ACSF; $60 \mathrm{~min}, 34^{\circ} \mathrm{C}$ ) containing $119 \mathrm{~mm} \mathrm{NaCl}, 2.5 \mathrm{~mm} \mathrm{KCl}, 1.3$ $\mathrm{mM} \mathrm{MgSO}_{4}, 10 \mathrm{~mm} \mathrm{NaH}_{2} \mathrm{PO}_{4}, 26.2 \mathrm{~mm} \mathrm{NaHCO}, 2.5 \mathrm{mM} \mathrm{CaCl}_{2}$, and 11 $\mathrm{mm}$ glucose and then placed in a submerged recording chamber perfused with oxygenated ACSF at $28 \pm 2^{\circ} \mathrm{C}$. Field EPSPs (fEPSPs) in the CA1 stratum radiatum were recorded using an electrode filled with $1 \mathrm{M} \mathrm{NaCl}$. A glass electrode filled with ACSF was used to stimulate Schaffer collateral/commissural afferents. To evaluate the input-output relationships of synapses, the slopes of fEPSPs were plotted as a function of fiber volley amplitudes. Paired-pulse facilitation (PPF) of fEPSPs was measured using pairs of presynaptic fiber stimulation pulses separated by various intervals. In long-term potentiation (LTP) experiments, the stimulus intensity was maintained at one-third of the maximum evoked response. In long-term depression (LTD) experiments, the stimulus intensity was maintained at one-half of the maximum evoked response. Initial fEPSP slopes were normalized in each experiment using the averaged slope value during the control period ( -20 to $0 \mathrm{~min}$ ). EPSCs were recorded from CA1 pyramidal cells using a patch electrode (3-6 M $\Omega$ ) in the whole-cell voltage-clamp mode (Axopatch 1D; Molecular Devices). The pipette solution contained $122.5 \mathrm{~mm}$ cesium gluconate, $17.5 \mathrm{~mm}$ CsCl, 10 mм HEPES buffer, 0.2 mm EGTA, 8 mм NaCl, 2 mм Mg-ATP, and $0.3 \mathrm{~mm} \mathrm{Na}_{3}$-GTP, pH $7.2(290-300 \mathrm{mOsm})$. Picrotoxin $(100 \mu \mathrm{M})$ was added to the ACSF. The resting membrane potential $\left(\right.$ mapla $^{+/+}$, $78 \pm 1 \mathrm{mV} ;$ mapla ${ }^{-/-}, 76 \pm 2 \mathrm{mV}$ ) showed no significant difference between genotypes (12-14 slices from 9-11 animals were used for each value; $p>0.3$, Mann-Whitney $U$ test). The current-voltage relationships of NR channel currents were measured in the presence of 2,3dihydroxy-6-nitro-7-sulfonyl-benzo[f]quinoxaline (NBQX). The currents were normalized to values at $50 \mathrm{mV}$ EPSC. To measure the NMDA/non-NMDA ratio of synaptic currents, a stimulus intensity was set to evoke AMPA responses (at $-90 \mathrm{mV}$ ) that were half the maximum response. NMDA EPSCs were isolated by blocking AMPA currents with NBQX, raising the holding potential to $40 \mathrm{mV}$, and finally verified by elimination by superfusion with D-2-amino-5-phosponovaleric acid (50 $\mu \mathrm{M}$; Tocris Cookson). The ratio of NMDA/non-NMDA currents was calculated from the peak amplitudes at 40 and $-90 \mathrm{mV}$. Whole-cell patch-clamp recordings of NMDA and AMPA miniature EPSCs (mEPSCs) were performed on 13-17 DIV primary hippocampal neuronal cultures as described previously (Gong and De Camilli, 2008). pClamp9 (Molecular Devices) software was used for all electrophysiological data acquisition and analysis.

Histology. Tissue sections for conventional light and electron microscopy were prepared using standard techniques (Takei et al., 2000). Paraffin-embedded sections were stained using silver-gold according to the method of Bodian (Takei et al., 2000). Morphometry of electron micrographs was performed as described previously (Takei et al., 2000).

Immunocytochemistry. Cells at 16-23 DIV were fixed in cold methanol for $10 \mathrm{~min}$. Coverslips were incubated with primary antibodies in 5\% BSA overnight at $4^{\circ} \mathrm{C}$. Subsequent incubation for secondary antibodies was $30 \mathrm{~min}$ at room temperature. Images were quantified using $\mathrm{NIH}$ Image J software (available at http://rsbweb.nih.gov/ij).

Hippocampal neurons (19-21 DIV) stained with anti-MAP2 monoclonal antibody were used for the analysis of dendrite morphology. The number of branching points of dendrites was not significantly different between the genotypes (means \pm SEM; mapla ${ }^{+/+}, 1.01 \pm 0.16 / 10^{2} \mu \mathrm{m}$; map $1 a^{-/-}, 0.98 \pm 0.14 / 10^{2} \mu \mathrm{m}$; NS, Mann-Whitney $U$ test; 60 neurons from three mice were examined for each genotype). The mean MAP2 signal intensity was also not significantly different between mapla $a^{+/+}$ and map $1 a^{-1-}$ mouse neurons (means \pm SEM; mapla $a^{+/+}, 31.8 \pm 1.64$ A.U.; mapla ${ }^{-/-}, 30.3 \pm 1.68$ A.U.; NS, Mann-Whitney $U$ test; 60 neurons from three mice were examined for each genotype). These data preclude the possibility that altered morphology of dendrites of 
map $1 a^{-/-}$mouse neurons might affect the specific decrease of NR2A/2B localization.

Biochemistry. Western blots of total crude extracts, synaptoneurosomes, and the PSD fraction were performed as described previously (Yin et al., 2011). For immunoprecipitation, mouse forebrains were homogenized on ice in 1\% Triton X-100, $25 \mathrm{~mm}$ Tris, pH 7.5, and $150 \mathrm{~mm}$ $\mathrm{NaCl}$ with protease inhibitors. After centrifugation twice at $8000 \times \mathrm{g}$ for $10 \mathrm{~min}$ at $4^{\circ} \mathrm{C}$ to remove debris, homogenates were precleared with Protein-A Sepharose beads (GE Healthcare Pharmacia). Lysates were then incubated with $25 \mu \mathrm{l}$ of MAGmol Protein-A paramagnetic beads (Miltenyi Biotec) conjugated to antibodies at $4^{\circ} \mathrm{C}$ for $30 \mathrm{~min}$. Eluents containing immune complexes were collected using microcolumns and a $\mu$ Max separator (Miltenyi Biotec) and applied subsequently to immunoblot analysis. Surface expression analysis using biotinylation and crosslinking experiments with $\mathrm{BS}^{3}$ were performed as described previously (Tao et al., 2003). Preparation of microtubule pellet fraction was performed as described previously (Sato-Yoshitake et al., 1989).

Live imaging. GFP-NR2A and GFP-NR2B were gifts from R. Malinow (University of California San Diego, San Diego, CA; Barria and Malinow, 2002). These constructs were coexpressed along with untagged NR1 (splice variant NR1-1a) in cultured hippocampal cells (12-14 DIV), because their assembly with the NR1 subunit is essential for NR2 subunits to be transported from cell bodies to synapses (Fukaya et al., 2003). A modified $\mathrm{Ca}^{2+}$-phosphate transfection method was used for transfection (Yin et al., 2011). Six to $12 \mathrm{~h}$ after transfection, imaging was performed using confocal laser scanning microscopy (LSM710; Zeiss). Cells were maintained in minimal essential medium (MEM; Gibco) warmed to $37^{\circ} \mathrm{C}$ in the presence of $1 \mathrm{~mm}$ kynurenate, $1 \mu \mathrm{M}$ strychnine, and $1 \mu \mathrm{M}$ tetrodotoxin. Images were analyzed using NIH Image J software.

RNAi assay using microRNA. BLOCK-iT Pol II miR RNAi Expression Vector kit (Invitrogen) was used according to the protocol of the manufacturer. Target sequences were designed on the Invitrogen website. The effect of knockdown by three sequences was examined using PSD-93 or PSD-95 immunolabeling. From the three sequences, one target was selected. For PSD-93 knockdown, the insert sequence was $5^{\prime}$-TGCT GATAAGAGTGAGTAATATCCGGGTTTTGGCCACTGACTGACCC GGATATCTCACTCTTAT-3'. For PSD-95 knockdown, the insert sequence was $5^{\prime}$-CCTGTGAAGATGCCTACCGTCCTGTCAGTCAGTG GCCAAAACAGGACGGTGAAGGCATCTTCAC-3'. Bold nucleotides indicate antisense target sequences. PSD-93 or PSD-95 knockdown was verified by the reduced signal intensity of endogenous proteins in hippocampal cultured neurons transfected with the microRNA (miR) RNAi vector. A vector pcDNA TM6.2-GW/ \pm RFP-miR-neg-control, which allowed formation of a pre-miR hairpin sequence predicted not to target any known vertebrate gene, was used for control experiments.

Antibodies. The primary antibodies used in this study were synaptophysin (p38) mAb (YE269; Abcam), NR2A and NR2B polyclonal antibodies (pAbs; Invitrogen), PSD-93 pAb (gift from S. Tomita, Yale University, New Haven, CT and D. S. Bredt, Johnson \& Johnson Research and Development, New Brunswick, NJ; Kim et al., 1996), PSD-95 mAb (7E3-1B8; Affinity BioReagents), GluR1 pAb (Millipore), Kv1.4 pAb (Millipore), MAP1A mAb (HM-1, Sigma-Aldrich; 1F4, Shiomura and Hirokawa, 1987a,b), MAP1B mAb (1B6; Sato-Yoshitake et al., 1989), MAP2 mAb (HM-2; Sigma-Aldrich), $\alpha$-tubulin mAb (DM1A; SigmaAldrich), and $\beta$-actin mAb (AC-15; Sigma-Aldrich), $\alpha$-actinin mAb (EA-53, Sigma-Aldrich), GABA $\mathrm{A} \beta 2 / 3$ mAb (BD17; Millipore), Gephyrin $\mathrm{mAb}$ (GlyR7a; Synaptic Systems), and Pur $\alpha$ pAb (Hirokawa et al., 2009). Secondary antibodies conjugated to Alexa Fluor 488 or 568 were purchased from Invitrogen.

\section{Results}

\section{Phenotypes of MAP1A knock-out mice}

To examine in vivo functions of MAP1A, mouse lines with disrupted mapla genes were produced (Fig. 1A). Disruption of the mapla gene was verified by genomic Southern blotting (Fig. 1B), and the absence of MAP1A in the map1 $1 a^{-/-}$mouse brain was confirmed by Western blot analysis using two different specific antibodies (HM-1 and 1F4l; Shiomura and Hirokawa, 1987a,b;
Fig. 1C). Cross-breeding between heterozygous $(+/-)$ mutants generated mice of $+/+,+/-$, and $-/-$ genotypes at a Mendelian ratio of $\sim 1: 2: 1$ at postnatal day $(\mathrm{P}) 0$ (Fig. $1 D$ ). There was no significant difference in average body weights of $\mathrm{mapla}^{+/+}$and map $1 a^{-/-}$mice at P0 (Fig. 1E). However, as a result of severe weight reduction and dehydration, a large percentage of map $1 a^{-/-}$mice died before they reached 4 weeks of age (Fig. $1 D$ ). To rescue dying mutant pups, we introduced foster mothers. We replaced map $1 a^{+/-}$biological mothers with foster ICR mothers, which were considered to have a better nursing ability than the mapla heterozygotes with inbred backgrounds. This replacement prevented the postnatal lethality of map $1 a^{-/-}$mice (Fig. $1 D ; p<0.05, \chi^{2}$ test). Surviving map $1 a^{-/-}$mice had reduced body weights, but they did not show a significantly greater lethality after reaching adulthood (Fig. 1D,F). We examined the brain structures of map $1 a^{-/-}$mice. There was no difference in the average brain weights between mapla $1 a^{+/+}$and $m a p 1 a^{-/-}$mice at P0 (Fig. $1 G$ ), whereas brain weights of map $1 a^{-/-}$mice were less than mapla $a^{+/+}$mice at 4 weeks of age (Fig. $1 H, I$ ). Histological examination revealed that the sizes of brain structures, such as the hippocampus, cerebellum, and corpus callosum, were proportionally smaller in map1 $a^{-1-}$ mouse brains compared with mapla $a^{+/+}$mice (Fig. $1 J-L$ ), although no additional specific anatomical deficits were found in map $1 a^{-/-}$mouse brains. We compared the structures of the basolateral amygdala (BLA) between map $1 a^{+/+}$and map $1 a^{-/-}$mouse brains. BLA plays a pivotal role during the formation of pavlovian fear memory (LeDoux, 2000). Paraffin-embedded sections stained by the Bodian method were examined by light microscopy (Teng et al., 2001). The shape of the neurons of mapla $a^{-1-}$ mouse BLA appeared normal compared with map $1 a^{+/+}$controls (Fig. 1M). We found no significant difference in the number of cells per area between mapla $a^{+/+}$

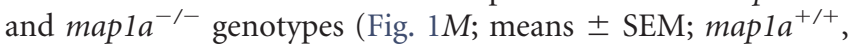
$6.57 \pm 0.57 \times 10^{-4} \mu^{-2} ;$ map $1 a^{-/-}, 6.92 \pm 0.24 \times 10^{-4}$ $\mu \mathrm{m}^{-2}$; NS, Mann-Whitney $U$ test; three mice at $4-5$ weeks of age were examined for each genotype).

We used electron microscopy for detailed examinations of the synapse ultrastructure in map $1 a^{-1-}$ mouse brains. Synaptic density, synaptic morphology, and sizes of PSDs were unchanged in the map $1 a^{-/-}$mouse nervous system (Fig. $1 N-Q$ ). Furthermore, the number and density of microtubules in $m a p 1 a^{-1-}$ sciatic nerves did not differ from those in mapla $a^{+/+}$mice (data not shown), suggesting that microtubule stability was maintained in the absence of MAP1A, possibly because of other neuronal microtubule stabilizers, such as tau, which compensate for the lack of MAP1A (Harada et al., 1994). Thus, apart from the nonspecific/proportional size reductions, we found no specific morphological alterations in map $1 a^{-1-}$ mouse brains.

\section{Memory disturbances in mapla ${ }^{-/-}$mice}

In contrast to tau, MAP2, and MAP1B, which are expressed abundantly in developing neurons (Hirokawa, 1994), MAP1A expression rises during the second postnatal week in the brain and remains constant thereafter (Schoenfeld et al., 1989; Tucker et al., 1989). This profile correlates well with the time course of generation and maintenance of synapses, suggesting that MAP1A could have a role in synaptic functions (Cornea-Hébert et al., 2002; Szebenyi et al., 2005). Considering these properties, in conjunction with previous findings on MAP1A interaction with neurotransmitter receptor-anchoring proteins, such as PSD-93 and PSD-95 (Brenman et al., 1998; Ikeda et al., 2002; Reese et al., 2007), we examined their memory functions. A fear conditioning test (Crawley, 2000), which assesses a form of associative learning 

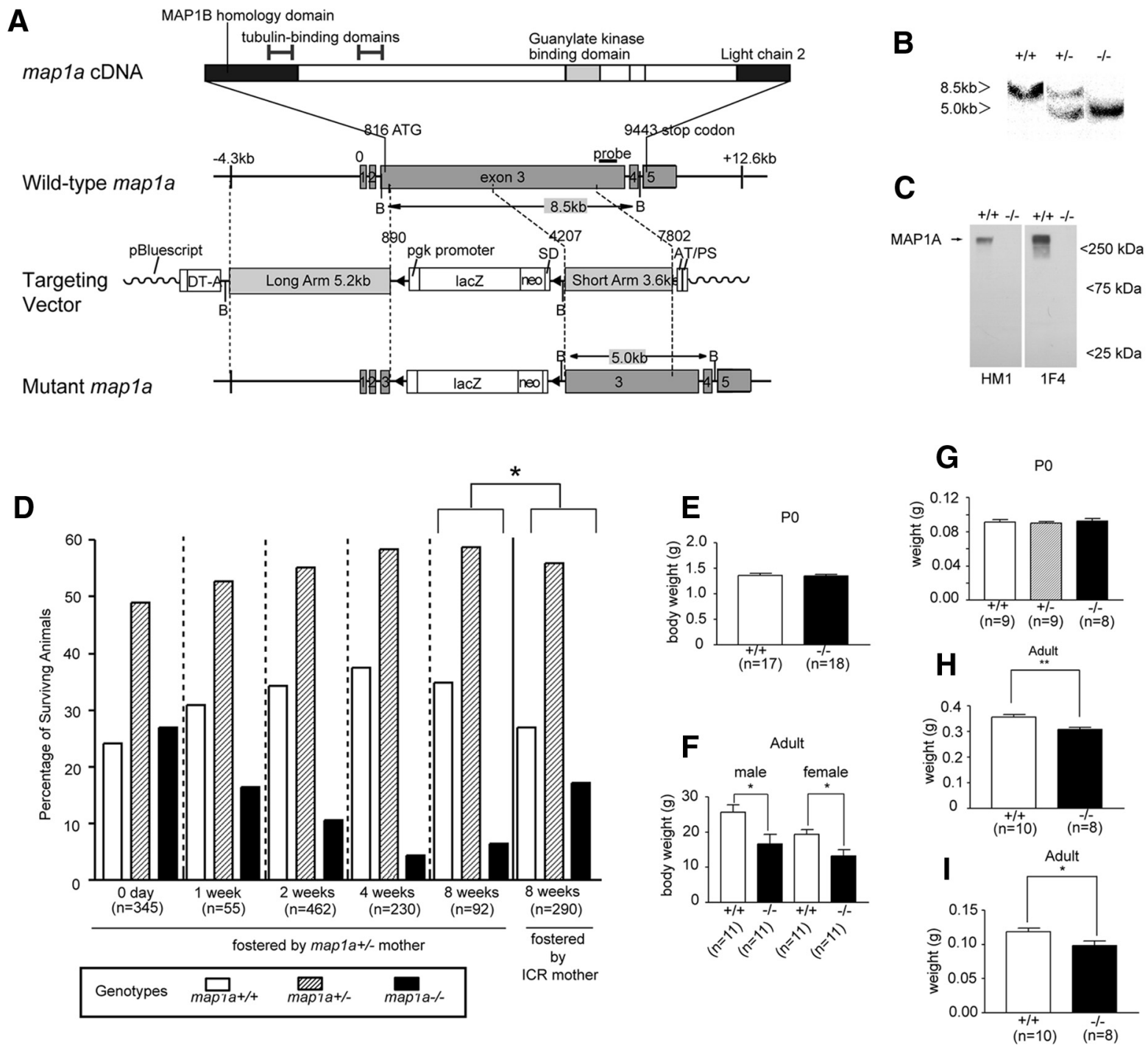

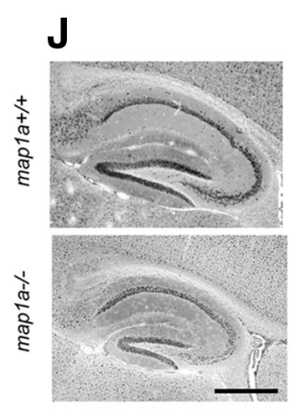

K
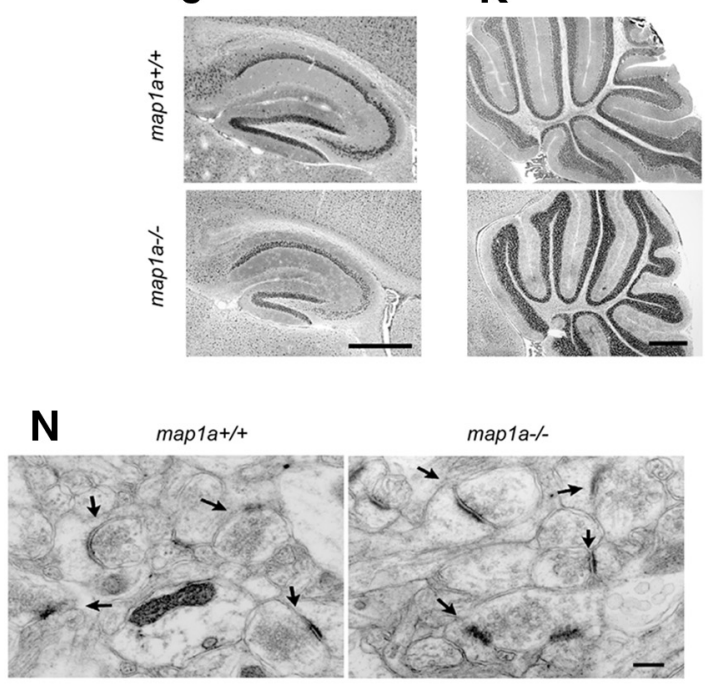

$\mathbf{L}$

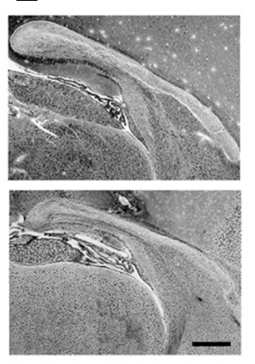

M

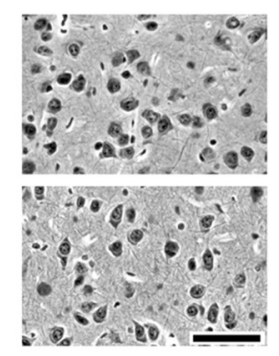

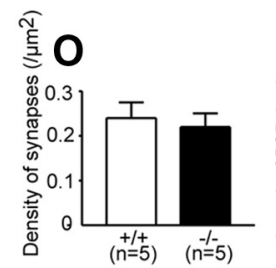
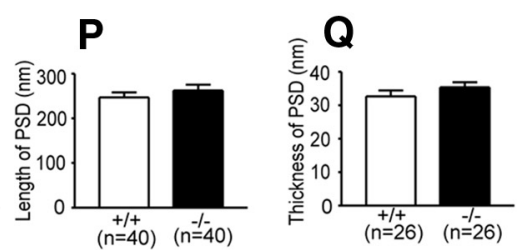

Figure 1. Phenotypes of map $1 a^{-1-}$ mice. $A$, Schematic of the map $1 a$ cDNA structure, the wild-type map $1 a$ allele, the targeting vector, and the targeted map $1 a$ allele. The numbered gray boxes in the wild-type map 1a locus mark the positions of exons $1-5$, which comprise the entire coding sequence. B, BamH1. B, Southern blot analysis of tail genomes after digestion with BamH1. The wild-type and mutant map $1 a$ alleles can be identified as 8.5 and $5.0 \mathrm{~kb}$ fragments, respectively. C, Western blot analysis of MAP1A protein in whole-brain lysates of $m a p 1 a^{+/+}$and map $1 a^{-/-}$mice using two different anti-MAP1A antibodies (HM-1 and 1F4). D, Percentages of animals of each genotype in each age group. $\boldsymbol{E}$, Body weights of mice at P0. F, Body weights of adult mice (8-10 weeks of age). $\mathbf{G}-\boldsymbol{I}$, Brain weight measurements show that map $1 a^{-1-}$ mice have significantly smaller cerebrums $(\boldsymbol{H})$ and cerebella $(\boldsymbol{I})$ than wild-type mice at $8-12$ weeks of age, whereas the weights of brains of mice at P0 did not differ among genotypes $(\boldsymbol{G}) .{ }^{*} p<0.05,{ }^{* *} p<0.01$, Student's $t$ test. $\boldsymbol{J}-\boldsymbol{M}$, Histological analyses of hippocampus (J), cerebellum (Figure legend continues.) 
A

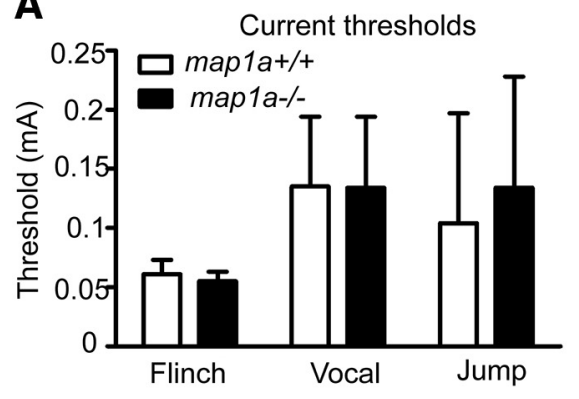

C

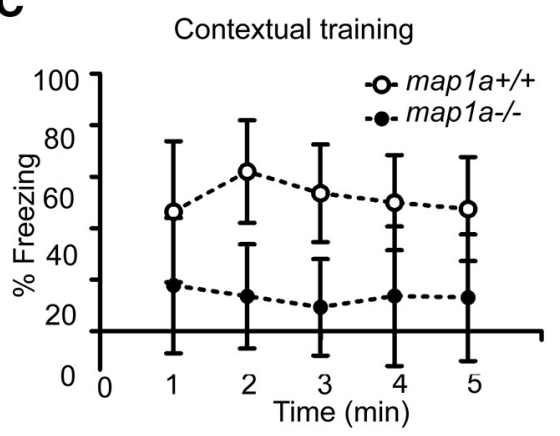

E

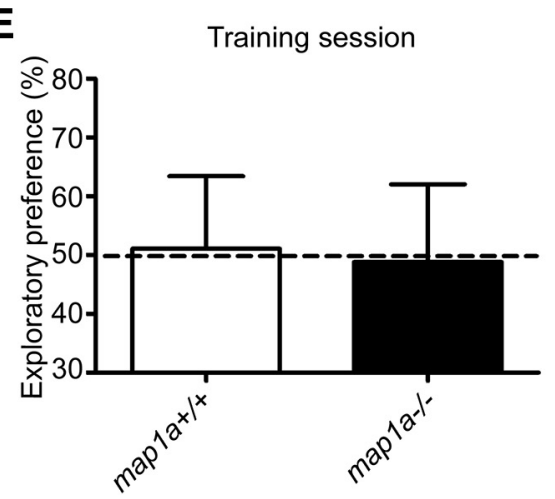

B

Training trial

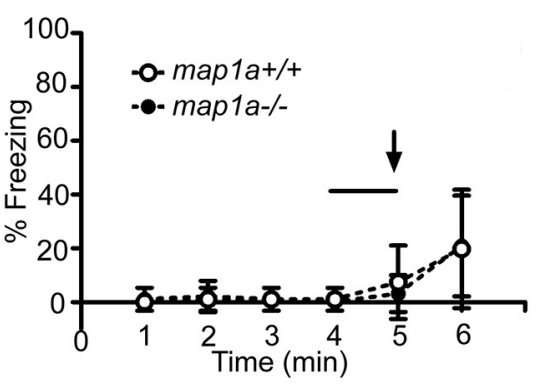

D
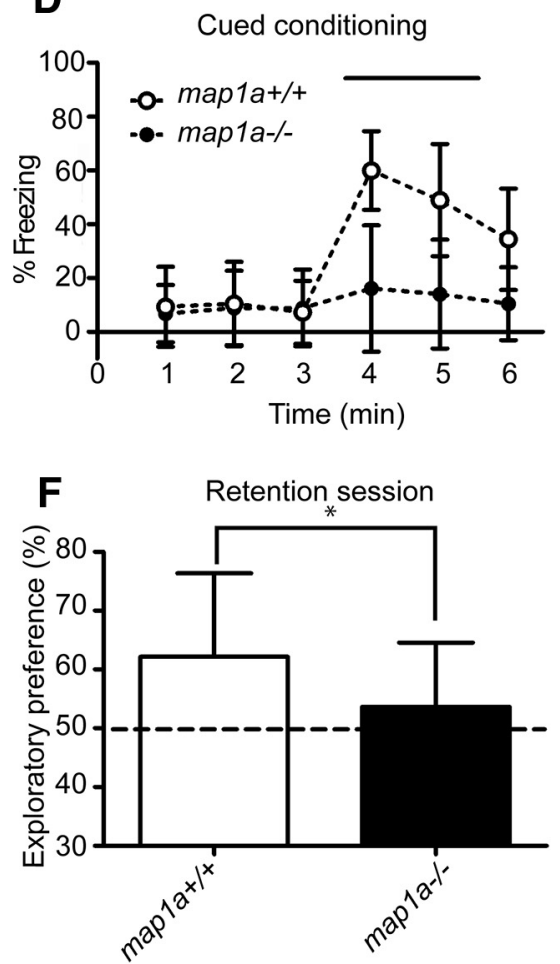

tailed Mann-Whitney $U$ test), indicating that pain sensitivity was normal in mapl $1 a^{-1-}$ mice. Two different CSs were applied for fear conditioning: (1) a tone (tone-dependent conditioning); and (2) a context of experimental chamber (contextual conditioning; Crawley, 2000). On the conditioning day, the mice showed few freezing responses, with no differences between map $1 a^{+/+}$and mapla $a^{-/-}$ mice (Fig. 2B). On the following day, their freezing behaviors were also monitored. Under both fear conditioning paradigms, map $1 a^{-1-}$ mice displayed few freezing responses (Fig. 2C,D; map1a $a^{+/+}, n=16$; map $1 a^{-/-}, n=16 ;{ }^{* *} p<0.01$, two-way ANOVA). Next, we measured recognition memory of mapla $1 a^{-/-}$mice using the novel recognition task, which is dependent on hippocampal function (Tang et al., 1999). map $1 a^{+/+}$and $m a p 1 a^{-/-}$mice spent the same amount of time exploring two identical objects during training sessions (Fig. 2E; mapla $a^{+++}, n=14$; map $1 a^{-1-}, n=14$; NS, two-tailed MannWhitney $U$ test), showing normal levels of locomotor activity and curiosity in map $1 a^{-/-}$mice. After training, the mice were tested at a $24 \mathrm{~h}$ retention interval. map $1 a^{+/+}$mice showed a significant preference for the novel object, whereas map $1 a^{-/-}$mice exhibited decreased preference for the novel object (Fig. 2F; mapla $a^{+/+}, n=14 ;$ mapla $^{-/-}, n=14$; ${ }^{*} p<0.05$, two-tailed Mann-Whitney $U$ test). These data suggest that disruption of the map $1 a^{-/-}$gene resulted in perturbation of memory processes, regardless of the paradigms of memory tasks.

Figure 2. Memory deficits in map $1 a^{-/-}$mice. Means \pm SDs are shown. $A$, Current thresholds of map $1 a^{+/+}$(open boxes) and

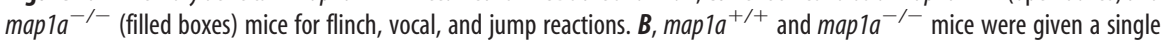
training trial. The solid line indicates tone duration (CS), whereas the arrow indicates a $2 \mathrm{~s}$ shock (US). $C$, Contextual conditioning test at $24 \mathrm{~h}$ after training. $\boldsymbol{D}$, Tone-dependent cued conditioning test at $24 \mathrm{~h}$ after training. $\boldsymbol{E}, \boldsymbol{F}$, Novel recognition test. $\boldsymbol{E}$, Exploratory preference during training session. The dotted line represents chance performance. $\boldsymbol{F}$, Exploratory preference in the retention test. ${ }^{*} p<0.05$.

between an aversive footshock (US) and a CS, was examined. Before starting, we examined whether the map $1 a^{-/-}$mutation altered nociceptive reactions to shock, because changes in pain sensitivity affect the conditioning process (Crawley, 2000). In both map1 $a^{-1-}$ mice and controls, common reactions (flinch, jump, and vocalization) were elicited with similar current intensities (Fig. $2 \mathrm{~A}$; map $1 a^{+/+}, n=10$; map1 $a^{-/-}, n=10$; NS, two-

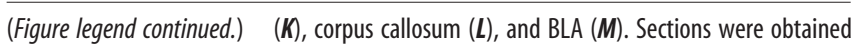
from mice at $4-5$ weeks of age and stained using the Bodian method. Scale bars: $J-L, 0.5 \mathrm{~mm}$; $M, 0.1 \mathrm{~mm}$. N-Q, Electron microscopic analysis. Brains obtained from P19-P24 mice of each genotype were analyzed. $\boldsymbol{N}$, Synapses in the hippocampal CA1 region are shown. Arrows indicate synaptic contacts with PSDs. Scale bar, $2 \mu \mathrm{m} . \mathbf{0}-\mathbf{Q}$, Morphometric analysis of synapses in the hippocampal CA1 region. $\boldsymbol{O}$, Synaptic densities. $n$, Number of mice examined. $\boldsymbol{P}$, Lengths of PSD. n, Number of synapses examined. $\boldsymbol{Q}$, Thickness of PSD. n, Number of synapses examined. In $\boldsymbol{P}$ and $\mathbf{Q}$, data were collected from two mice of each genotype. Means \pm SEMs are shown.

\section{Reduced synaptic plasticity in $m a p 1 a^{-/-}$} mouse neurons

Electrophysiological analysis of acute slices of the hippocampal CA1 region was performed to gain insight into the pathophysiological mechanisms underlying memory disturbances in map $1 a^{-1-}$ animals. We first examined the input-output relationship between fiber excitability and synaptic strength to assess synaptic transmission in map $1 a^{-1-}$ mouse neurons. The amplitude of the fiber volley in Schaffer collaterals was compared with the slope of fEPSPs stimulated with various electrical intensities. Input-output

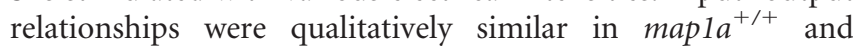
map $1 a^{-1-}$ mice (Fig. $3 A$ ). For quantitative analysis, we compared the slopes of these input-output curves between $+/+$ and $-/-$ genotypes. No significant difference was observed (Fig. 3B;

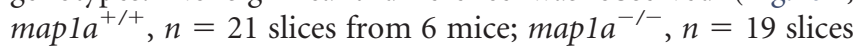
from 6 mice; NS, two-tailed Mann-Whitney $U$ test). Subsequently, we examined synaptic plasticity. First, we tested PPF with various intervals between the paired stimuli. No significant difference was found in the extent of PPF between map $1 a^{-1-}$ and

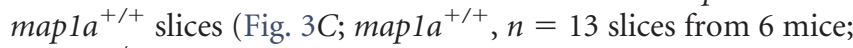
mapla $a^{-/-}, n=13$ slices from 6 mice; NS, repeated-measures 
A

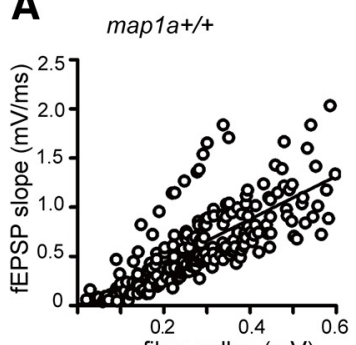

fiber volley $(\mathrm{mV})$

D
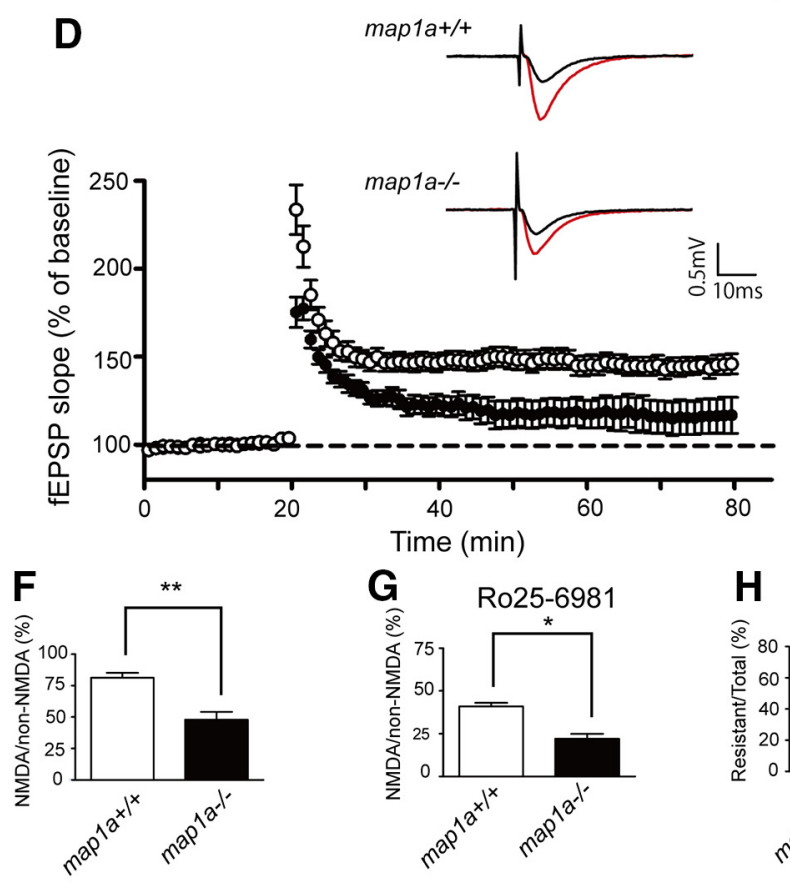

J

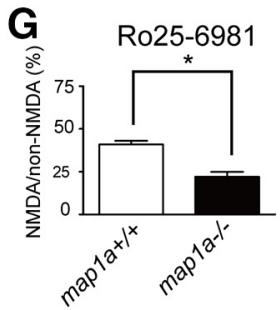

map1a+/+
B
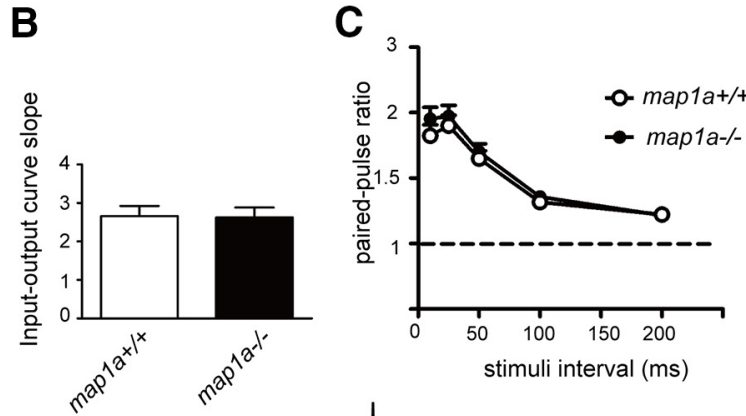

E map1at/+

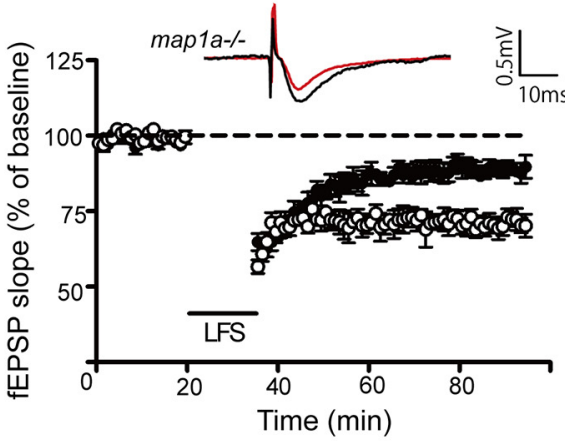

H

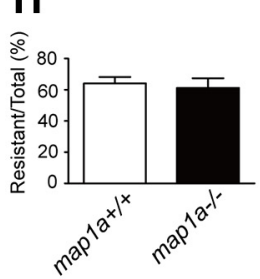

I
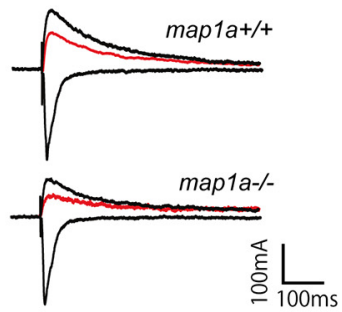

$\mathrm{K}$

map1a-/-

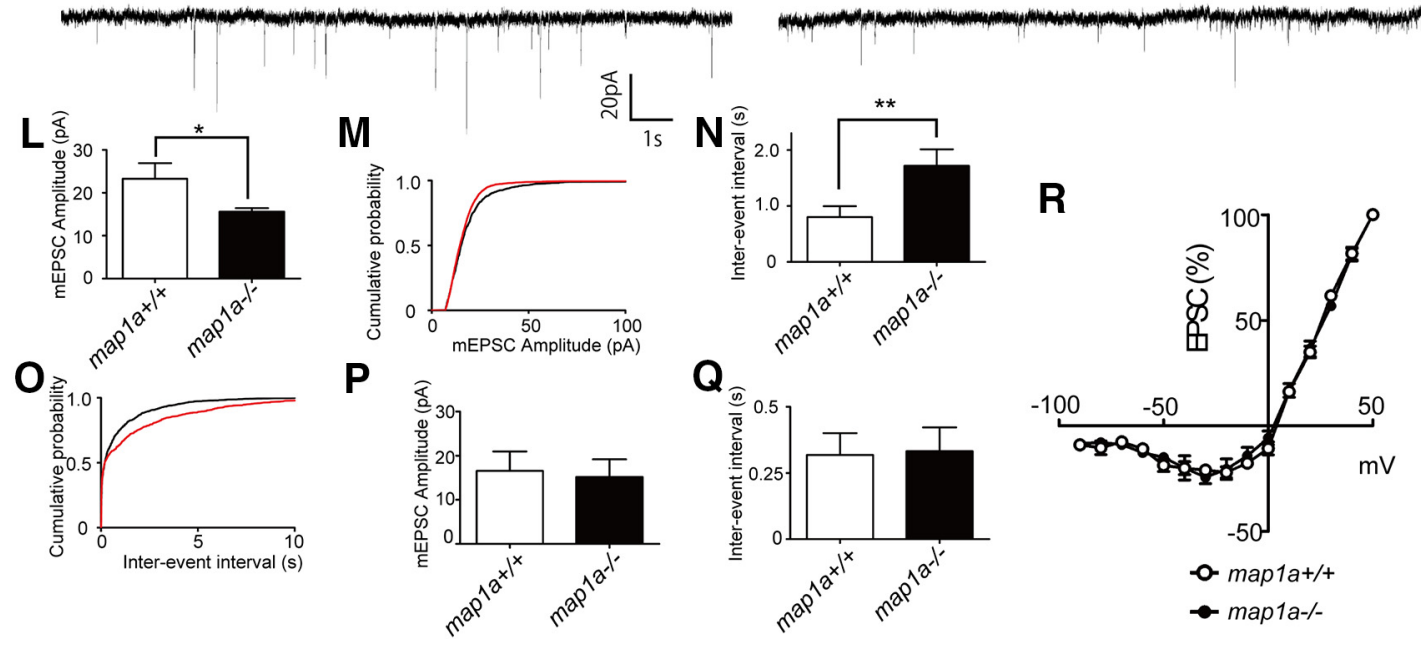

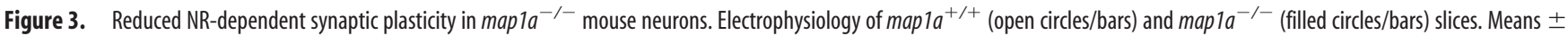
SEMs are shown. $A, B$, Baseline synaptic transmission. $A$, Input- output relationships of fEPSPs. $B$, Summary of input- output curves. $C$, PPF of fEPSPs was measured using pairs of presynaptic fiber

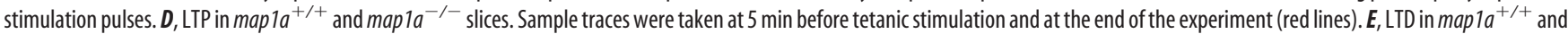
map $1 a^{-1-}$ slices. Sample traces were taken at 5 min before low-frequency stimulation (LFS) and at the end of the experiment (red lines). $\boldsymbol{F}$, Ratios of peak NMDA/non-NMDA receptor channel currents. G, Ratios of peak NMDA/non-NMDA receptor channel currents in the presence of Ro25-6981 (5 $\mu \mathrm{M})$. $\boldsymbol{H}$, Ro25-6981 resistant/total ratio of NMDA/non-NMDA receptor channel currents was

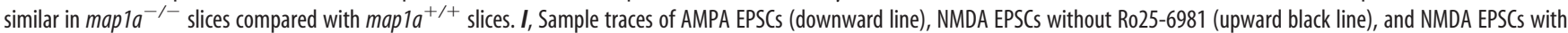
Ro25-6981 (upward red line) recorded at -90 and $40 \mathrm{mV}$, respectively. $\boldsymbol{J}, \boldsymbol{K}$, Typical NMDA mEPSC recordings from map $1 a^{+/+}(\boldsymbol{J})$ and map $1 a^{-/-}(\boldsymbol{K})$ neurons $(14$ DIV). $\boldsymbol{L}, \boldsymbol{M}$, Average $(\boldsymbol{L})$ and

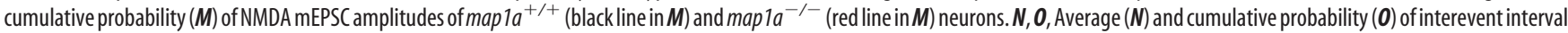
of NMDA mEPSC amplitudes of map1a ${ }^{+/+}$(black line in $\mathbf{0}$ ) and map1a ${ }^{-/-}$(red line in $\mathbf{0}$ ) neurons. $\boldsymbol{P}, \boldsymbol{Q}$, Average of AMPA mEPSC amplitude $(\boldsymbol{P})$ and interevent interval $(\mathbf{Q})$. $\boldsymbol{R}$, Current-voltage relationships of NR channel currents. ${ }^{*} p<0.05,{ }^{* *} p<0.01$. 
ANOVA), indicating that short-term presynaptic plasticity was intact in map $1 a^{-1-}$ slices. Second, we examined LTP, an NRdependent form of plasticity (Malenka and Nicoll, 1999). Conventional tetanic stimulation $(100 \mathrm{~Hz}, 1 \mathrm{~s}$ duration) caused a long-lasting increase in synaptic strength in map $1 a^{+/+}$slices. The extent of LTP was decreased in mapla ${ }^{-1-}$ slices (Fig. 3D; map $1 a^{+/+}, n=11$ slices from 11 mice; map $1 a^{-/-}, n=11$ slices from 11 mice; ${ }^{\star} p<0.05$, compared at 58-60 min after tetanic stimulation). Third, we examined LTD, another form of synaptically induced plasticity evoked by a low-frequency train of $1 \mathrm{~Hz}$ for $15 \mathrm{~min}$ (Collingridge et al., 2010). The level of LTD was significantly reduced in map $1 a^{-/-}$slices compared with those in map $1 a^{-1-}$ slices (Fig. 3E; mapla $a^{+/+}, n=5$ slices from 5 mice; map $1 a^{-/-}, n=11$ slices from 11 mice; ${ }^{\star} p<0.05$, compared 45 min after stimulation train). Next, we performed whole-cell patch-clamp recordings of CA1 pyramidal cell neurons to compare receptor function between map $1 a^{+/+}$and map $1 a^{-/-}$slices (Sakimura et al., 1995). NMDA channel currents, expressed as ratios to $20 \mu \mathrm{M}$ NBQX-sensitive non-NR channel currents, were reduced in map $1 a^{-/-}$slices compared with mapla $a^{+/+}$slices (Fig. $3 \mathrm{~F}, \mathrm{I} ; \mathrm{map} 1 \mathrm{a}^{+/+}, n=10$ slices from 10 mice; map $1 a^{-/-}, n=10$ slices from 8 mice; ${ }^{\star} p<0.05$, two-tailed Mann-Whitney $U$ test $)$. We treated hippocampal slices with Ro25-6981 [R-( $R, S)-\alpha-(4-$ hydroxyphenyl)- $\beta$-methyl-4-(phenylmethyl)-1-piperidine propranol; $5 \mu \mathrm{M}$, a blocker of NRs containing the NR2B subunit] to assess the difference in subunit compositions of NRs between genotypes. Application of Ro25-6981 to slices derived from map $1 a^{+/+}$mice reduced NR-mediated EPSCs, with a similar effect observed in map $1 a^{-/-}$slices (Fig. 3G,I; mapla $a^{+/+}, n=10$ slices from 10 mice; map $1 a^{-/-}, n=10$ slices from 8 mice; ${ }^{\star} p<$ 0.05, two-tailed Mann-Whitney $U$ test). The Ro25-6981-resistant/total ratio of NR-mediated EPSCs in map $1 a^{-1-}$ slices was not different from map $1 a+/+$ slices (Fig. $3 H$; map $1 a^{+/+}, n=10$ slices from 10 mice; map $1 a^{-/-}, n=10$ slices from 8 mice; NS, two-tailed Mann-Whitney $U$ test), indicating that levels of relative contribution of NR2B in NR-mediated EPSCs was similar between mapla $^{+/+}$and mapla $a^{-/-}$genotypes. We then compared mEPSCs between map $1 a^{+/+}$and map $1 a^{-/-}$mouse neurons. The amplitudes of mEPSCs generated by the selective activation of NRs (as analyzed by the addition of $20 \mu \mathrm{M}$ glycine, removal of extracellular $\mathrm{Mg}^{2+}$, and blocking of AMPA receptors with $20 \mu \mathrm{M}$ NBQX; Gong and De Camilli, 2008) were smaller, and the interevent intervals were increased in map $1 a^{-1-}$ cells (Fig. 3J-O). Both amplitudes and interevent intervals of AMPAmediated mEPSCs were similar in the two genotypes (Fig. $3 P, Q$ ). There was also no significant difference in current-voltage relationships of NR channel currents (Fig. $3 R$; map $1 a^{+/+}, n=4$ slices from 3 mice; map $1 a^{-/-}, n=6$ slices from three mice). These data indicate that postsynaptic NR function was attenuated in mapla $a^{-/-}$mutant mice.

\section{Reduced surface expression of NR2A/2B in mapla ${ }^{-/-}$mouse neurons}

The memory disturbances of map $1 a^{-/-}$mice and impaired NR function in mapla $a^{-/-}$cells prompted us to examine expression and cellular localization of $\mathrm{NR} 2 \mathrm{~A} / 2 \mathrm{~B}$ receptors in map $1 a^{-1-}$ mouse neurons, because they are critical for memory formation by gating synaptic plasticity (Morris, 1989; Sakimura et al., 1995; Tsien et al., 1996). A series of biochemical analyses was performed. Expression levels of various cytoskeletal and synaptic proteins, including NR2A/2B and PSD-93/95, in total brain extracts of map $1 a^{-/-}$mice were similar to those in map $1 a^{+/+}$mice extracts (Fig. 4A, B). However, NR2A/2B levels in synaptoneuro- somal membranes and PSD fractions were decreased significantly in map $1 a^{-1-}$ mouse neurons (Fig. 4C,D). Results showed that PSD-93 expression was also slightly, but significantly, decreased (Fig. 4C,D).

Because these biochemical data suggest that synaptic localization of NR2A/2B was altered in mapla ${ }^{-1-}$ mouse neurons, we compared surface expression levels of NR2A/2B between map $1 a^{+/+}$and map $1 a^{-/-}$primarily cultured neurons. Surface protein was labeled with biotin and precipitated, followed by quantitative Western blot analysis of the ratio of surface/total protein (Tao et al., 2003). This analysis showed that the average level of surface NR2A/2B in map $1 a^{-/-}$mice was reduced compared with map $1 a^{+/+}$mice (Fig. $4 E, F ;{ }^{\star} p<0.05$, MannWhitney $U$ test; four to six mice were examined for each value). In contrast, surface expression of the AMPA-receptor subunit GluR1 was not affected (Fig. 4G; NS, five mice were examined for each value, Mann-Whitney $U$ test), excluding the possibility that nonspecific changes in map $1 a^{-/-}$neurons resulted in the altered surface expression of receptor proteins. As a control, the intracellular protein $\alpha$-actinin showed very low signal for surface expression (Fig. 4H). To confirm changes in surface expression of $\mathrm{NR} 2 \mathrm{~A} / 2 \mathrm{~B}$, we applied a membrane-impermeable crosslinking reagent, $\mathrm{BS}^{3}$, to hippocampal cultures to crosslink proteins exposed on the cell surface. Because crosslinked proteins are unable to enter polyacrylamide gels, the intracellular pool of proteins could then be measured by quantitative Western blot analysis (Tao et al., 2003). A significant increase in the intracellular pool of NR2A/2B was observed in map1a $a^{-/-}$acute slices compared with map $1 a^{+/+}$(Fig. $4 I, J$; ${ }^{\star} p<0.05$, four to five mice were examined for each value, Mann-Whitney $U$ test), confirming the results obtained from the biotin-labeling experiment. Intracellular levels of $\alpha$-actinin, which was not crosslinked by $\mathrm{BS}^{3}$, remained unchanged between genotypes (Fig. 4J; NS, four mice were examined for each value, Mann-Whitney $U$ test). Thus, the lack of MAP1A resulted in reduced surface expression of NR2A/2B.

We then examined possible alterations of NR2A/2B localization in map $1 a^{-1-}$ mouse neurons using immunocytochemistry. The cultures were fixed and double-labeled with antibodies against NR2A and the dendrite-specific protein MAP2 (Fig. 5A) or antibodies against NR2B and MAP2 (Fig. 5D). The lack of $M A P 1 A$ resulted in decreased immunocytochemical signal intensity of NR2A/2B clusters (Fig. 5A, B, D,E; 88-91 neurons from three animals were examined for each value; two-tailed MannWhitney $U$ test), whereas the density of NR2A/2B clusters remained unchanged (Fig. 5C,F; 88-91 neurons from three animals were examined for each value; two-tailed Mann-Whitney $U$ test). These data suggest that synaptic accumulation of $\mathrm{NR} 2 \mathrm{~A} / 2 \mathrm{~B}$ decreased in dendrites of map $1 a^{-/-}$mouse neurons. Immunoreactivity and cluster density of synaptophysin remained unchanged in map1a $a^{-/-}$mouse neurons (Fig. 5G-I; 39-45 neurons from three animals were examined for each value; two-tailed Mann-Whitney $U$ test), suggesting that the formation of presynaptic terminals in map $1 a^{-/-}$mouse neurons was within the normal range. Immunoreactivity and cluster density of other receptors or synaptic proteins, GluR1 (subunits of AMPA-type glutamate receptors), $\mathrm{GABA}_{\mathrm{A}} \mathrm{R} \beta 2\left(\mathrm{GABA}_{\mathrm{A}}\right.$ receptor subunit), Gephyrin (glycine receptor interacting protein), and Pur $\alpha$ (a component of RNA-transporting granule) remained unchanged (Fig. 5G-I; 52-77 neurons from three animals were examined for each value; two-tailed Mann-Whitney $U$ test), suggesting specific signal decreases of NR2A/2B clusters in mapla $a^{-/-}$mouse neurons. 

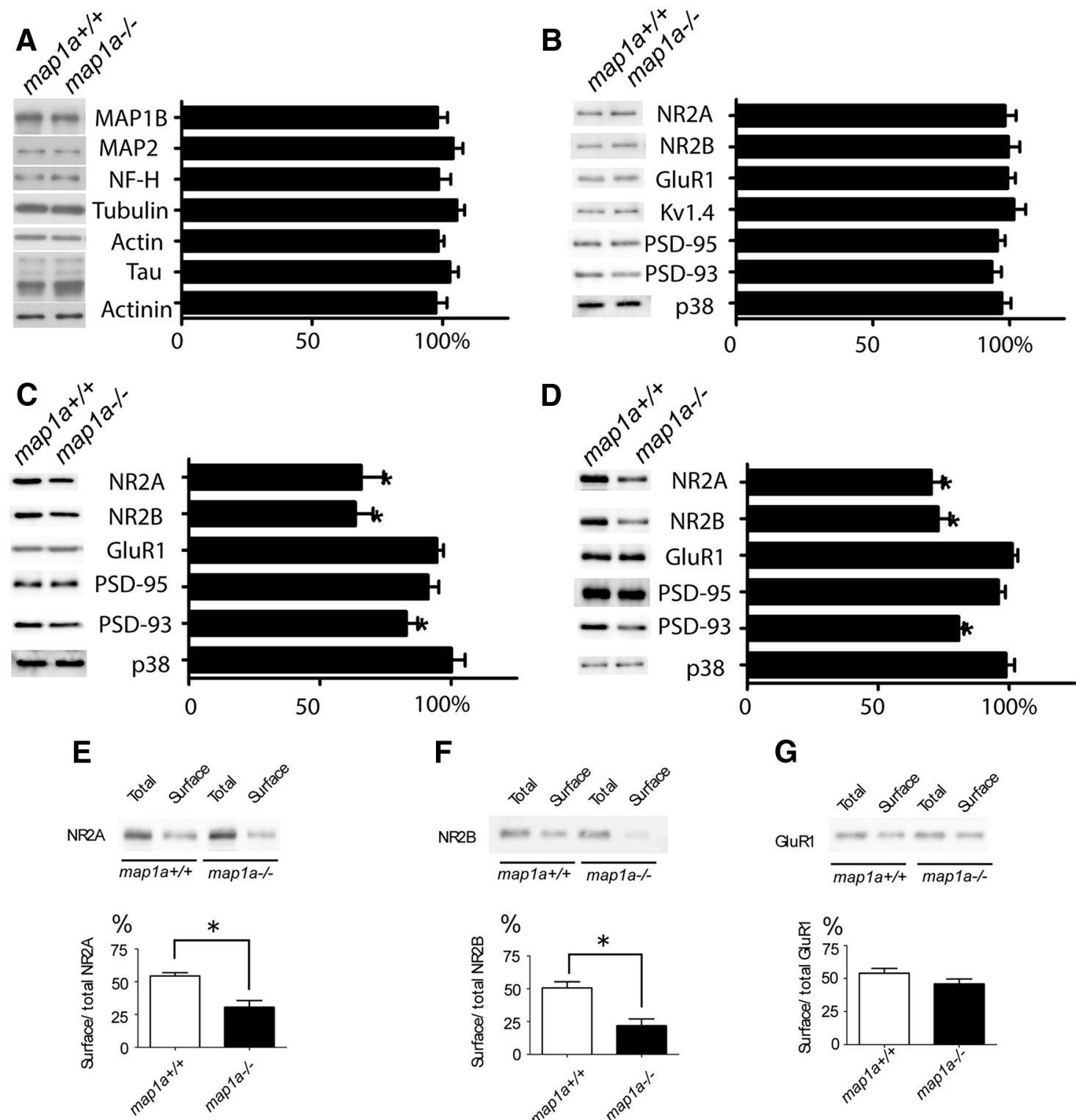

$\mathbf{F}$

G

NR2B
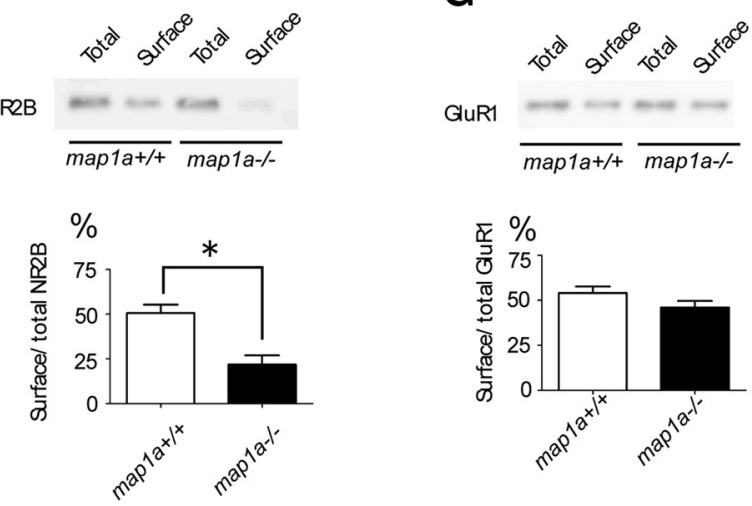

H
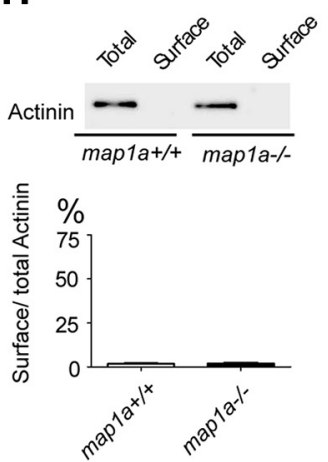

I

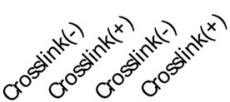

$\mathbf{J}$

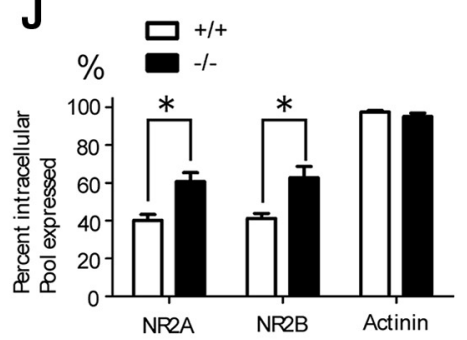

Figure 4. Reduced synaptic cell-surface NR2A/2B in map $1 a^{-/-}$mouse neurons. $\boldsymbol{A}, \boldsymbol{B}$, Immunoblots of brain extracts with antibodies specific for cytoskeletal $(\boldsymbol{A})$ and synaptic $(\boldsymbol{B})$ proteins. C, Expression of synaptic proteins in the synaptosomal fraction. $\boldsymbol{D}$, Expression of synaptic proteins in the PSD fraction. Data are expressed as means \pm SEMs. NF-H, Neurofilament H; GluR1, AMPA receptor subunit; Kv1.4, voltage-gated potassium channel; p38, synaptic vesicle protein. $\boldsymbol{E}-\boldsymbol{H}$, Quantitative analysis of NR2A $(\boldsymbol{E})$, NR2B $(\boldsymbol{F})$, GluR1 (G), and actinin $(\boldsymbol{H})$ expression on cell surfaces. The top depicts a blot showing total and biotinylated (surface) proteins. The bottom shows results of statistical analyses. $\boldsymbol{H}$, Intracellular cytoplasmic protein actinin was not biotinylated. Means \pm SEMs are shown. $I, J$, Quantitative analysis of the internal pool of NR2A, NR2B, and actinin using a crosslinking reagent $\left(B S^{3}\right)$. $I, B$ Blots showing samples from map1a ${ }^{+/+}$and map $1 a^{-/-}$mouse neurons with or without $\mathrm{BS}^{3}$ treatment. J, Statistical summaries. Means \pm SEMs are shown. ${ }^{*} p<0.05$. 
A
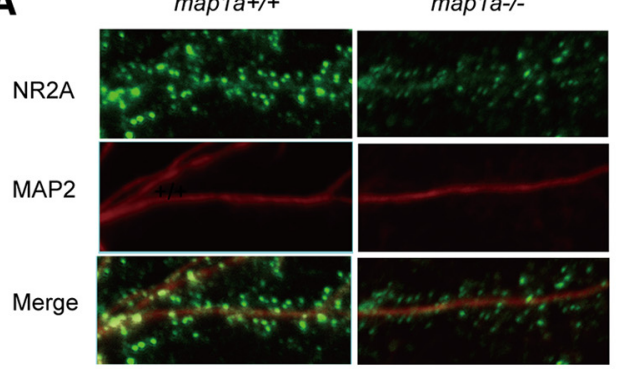

$5 \mu \mathrm{m}$

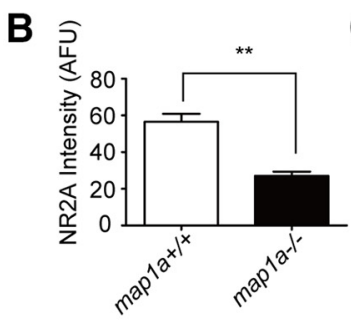

C

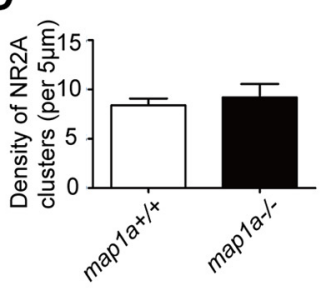

D

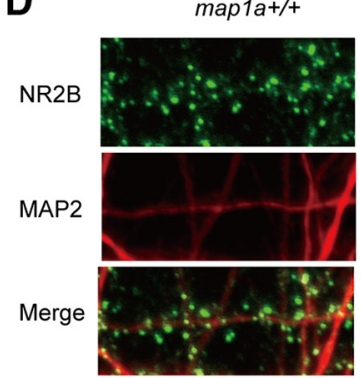

E

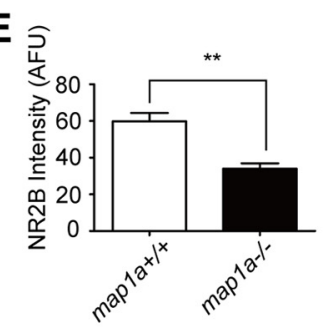

map1a-/-

G
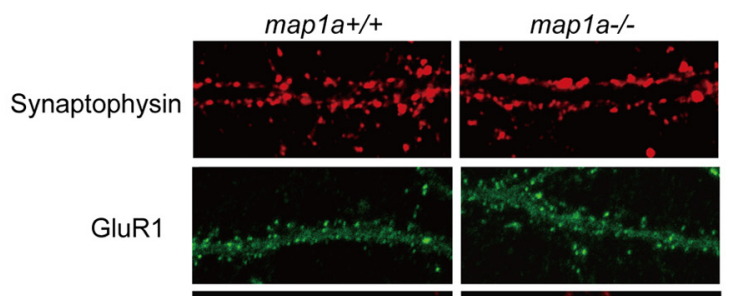

GABAA RB2/3

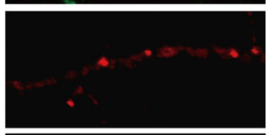

Gephyrin
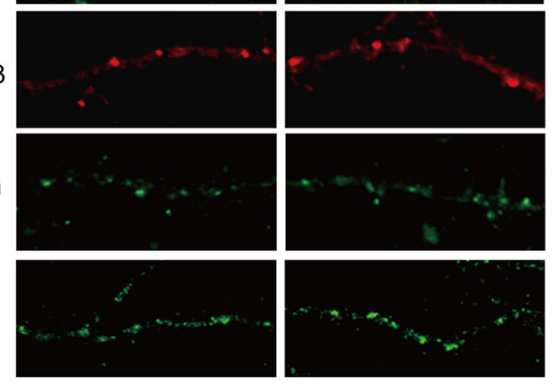

$5 \overline{\mu m}$

H
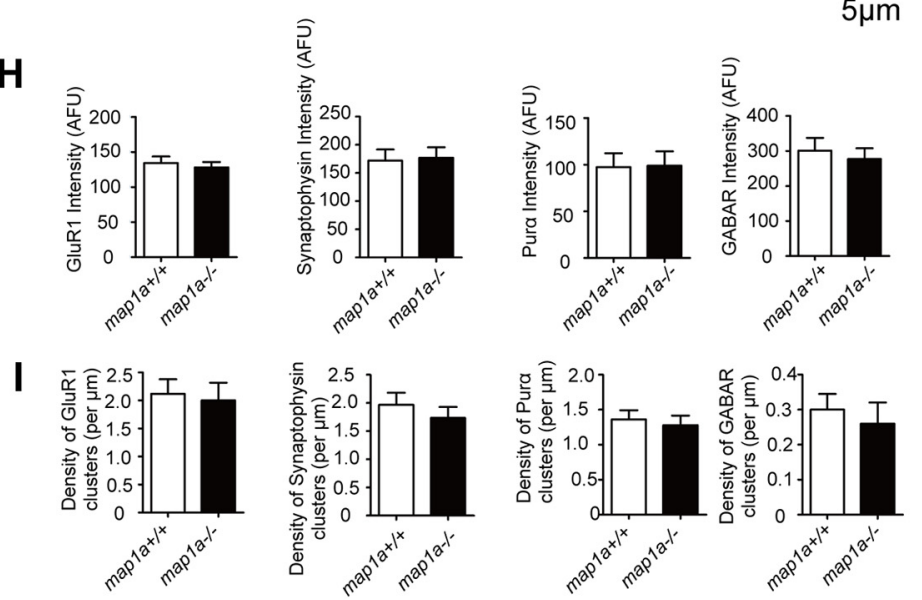

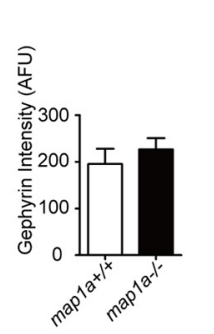

map1a-/-

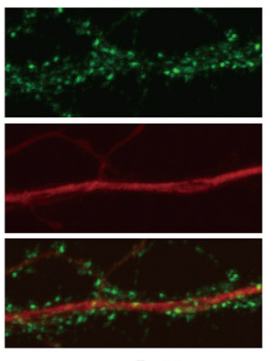

$5 \mu \mathrm{m}$

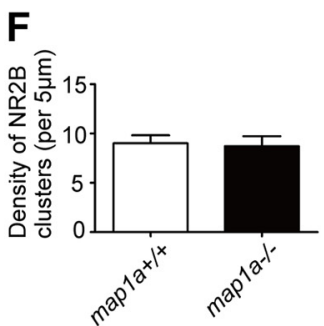

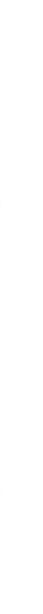$$
\text { (1) }
$$

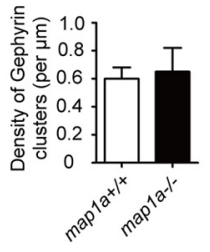

Figure 5. Reduced synaptic NR2A/NR2B expression in map1 $a^{-/-}$mouse neurons. $\boldsymbol{A}$, Representative images of dendrites double stained with anti-NR2A (green)/MAP2 (red) antibodies. $\boldsymbol{B}, \boldsymbol{C}$, Statistical analysis of NR2A immunocytochemistry images. $\boldsymbol{B}$, Mean signal intensities of individual NR2A clusters of map $1 a^{+/+}$and map $1 a^{-/-}$dendrites. $\boldsymbol{C}$, Mean densities of NR2A clusters along map $1 a^{+/+}$and map $1 a^{-/-}$dendrites. D, Representative images of dendrites double stained with anti-NR2B (green)/MAP2 (red) antibodies. $\boldsymbol{E}, \boldsymbol{F}$, Statistical analysis of NR2B immunocytochemistry images. $\boldsymbol{E}$, Mean signal intensities of individual NR2B clusters of map $1 a^{+/+}$and map $1 a^{-/-}$dendrites. $\boldsymbol{F}$, Mean densities of NR2A clusters along map $1 a^{+/+}$and map $1 a^{-/-}$dendrites. Means \pm SEMs are shown. G, Immunocytochemistry of hippocampal cultures at 21 DIV. Dendrites of map $1 a^{+/+}$and map1a ${ }^{-/-}$neurons were immunostained by anti-synaptophysin, anti-GluR1, anti-GABAR, anti-Gephyrin, and anti-Pur $\alpha$. $\boldsymbol{H}, \boldsymbol{I}$, Statistical analysis of signal intensities of each cluster in dendrites $(\boldsymbol{H})$ and density of clusters along dendrites $(\boldsymbol{I})$. Means \pm SEMs are shown. ${ }^{* *} p<$ 
Interaction between MAP1A and MAGUKs

To ascertain the molecular basis for reduced surface expression of NR2A/2B, we examined two major NR-scaffolding molecules, PSD-93 and PSD-95, which are known binding partners of MAP1A (Brenman et al., 1998; Ikeda et al., 2002). Because MAP1A also binds to microtubule and actin filaments (Tucker et al., 1989; Chien et al., 2005), it is thought that MAP1A makes a bridge between the microtubule/actin cytoskeleton and PSD93/95 scaffolding proteins (Brenman et al., 1998; Ikeda et al., 2002; Fig. 6A). Immunoprecipitation using anti-MAP1A monoclonal antibody HM-1 demonstrated that NR2A, NR2B, PSD-93/95, tubulin, and actin were coimmunoprecipitated with anti-MAP1A antibody from extracts of map $1 a^{+/+}$mice but not from map $1 a^{-/-}$mice (Fig. $6 B$ ). These results correlated with previous results (Brenman et al., 1998; Ikeda et al., 2002; Fig. $6 A, B)$. We speculated that a loss of MAP1A led to dissociation of PSD-93/95 from the cytoskeleton. To test this, we compared PSD-93 and PSD-95 levels in the microtubule pellet fractions (prepared with $20 \mu \mathrm{M}$ taxol) between map $1 a^{+/+}$and mapla $a^{-/-}$mouse neurons (Sato-Yoshitake et al., 1989; Fig. 6C,D). PSD-93 and PSD-95 levels in the microtubule pellet fractions of map $1 a^{-/-}$mouse neurons were reduced compared with map $1 a^{+/+}$mouse neurons (Fig. $6 D ;{ }^{\star} p<0.05$, Mann-Whitney $U$ test; five mice were examined for each value). These data suggested that PSD-93/95 detaches from microtubules in the absence of MAP1A.

\section{Enhanced activity-dependent degradation of PSD-93 in map $1 a^{-/-}$mouse neurons}

PSD-95 degradation is regulated by the ubiquitin-proteasome system in an activity-dependent manner (Mabb et al., 2014). Considering the possibility that a change in activity-dependent degradation of PSD proteins underlies the change in synaptic plasticity in mapla $a^{-/-}$mouse neurons, we measured PSD-93/95 levels before and after $\mathrm{KCl}$ stimulation and compared the extent of degradation between the two genotypes. After high potassium stimulation (50 mM, $15 \mathrm{~min}$ ), PSD-95 expression decreased significantly in mapla $a^{+/+}$neurons, as reported previously (Colledge et al., 2003; Fig. 7A-C). The level of PSD-95 decrease was slightly greater in map $1 a^{-/-}$neurons, although the difference between the genotypes was not statistically significant (Fig. $7 C)$. In contrast, the stimulation-induced decrease of PSD-93 was significantly enhanced in map1a $a^{-/-}$mouse neurons compared with map $1 a^{+/+}$mouse neurons (Figs. $7 D-F$ ). In both map $1 a^{+/+}$ and mapla $^{-1-}$ mouse neurons, decrease of PSD-93/95 was blocked by the proteasomal inhibitor MG-132 (carbobenzoxy-Lleucyl-L-leucyl-L-leucinal; $10 \mu \mathrm{M}$ ) treatment, suggesting that PSD-95 and PSD-93 were degraded through the proteasomeubiquitin pathway in both map $1 a^{+/+}$and map $1 a^{-/-}$mouse neurons (Fig. $7 A, B, D, E$ ). Immunocytochemical studies revealed that fluorescent intensities of PSD-95 were decreased signifi-
B

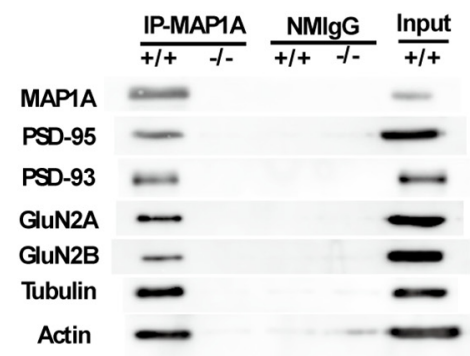

D

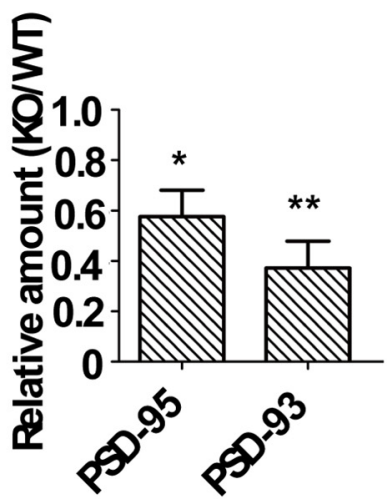

cantly in an activity-dependent manner, as reported previously (Colledge et al., 2003; Figs. 7G,I). The decreases in PSD-95 signal were slightly greater in mapla $a^{-/-}$neurons compared with map $1 a^{+/+}$neurons, although the difference was not statistically significant (Fig. 7J). In contrast, the decreased immunocytochemical signal intensity of PSD-93 puncta was significantly greater in mapla $a^{-/-}$mouse neurons than in mapla $a^{+/+}$mouse neurons (Figs. 7I). The proteasomal inhibitor MG-132 blocked the decreased PSD-93/95 in both $\mathrm{mapla}^{+/+}$and map1a $a^{-/-}$ mouse neurons, confirming involvement of the proteasomeubiquitin pathway in the activity-dependent decrease of PSD-93/ 95. These data suggest that the absence of MAP1A led to increased activity-dependent degradation of PSD-93, which is dependent on the ubiquitin-proteasome system.

\section{Altered dynamics of NRs in map1a ${ }^{-/-}$mouse neurons}

The possible effect of the absence of MAP1A on NR dynamics was examined in living neurons using live imaging of NR2A/2B subunits tagged with EGFP at the extracellular N terminus (NR2AEGFP and NR2B-EGFP; gift from R. Malinow; Barria and Malinow, 2002). These constructs were expressed in cultured hippocampal cells (12-14 DIV). Cell-surface expression of NR2A-EGFP and NR2B-EGFP in map1a $a^{-1-}$ neurons was reduced compared with map $1 a^{+/+}$neurons (Fig. 8A-C). To distinguish between the cytoplasmic pool and the surface pool of $\mathrm{NR} 2 \mathrm{~A} / 2 \mathrm{~B}$, neurons were treated with bromophenol blue (BPB), a membrane-impermeable reagent that quenches fluorescence of extracellularly exposed EGFP on the cell surface (Song et al., 2009). Addition of BPB to the medium highlighted signals of cytoplasmic EGFP-NR2A/2B by quenching postsynaptically lo- 
A

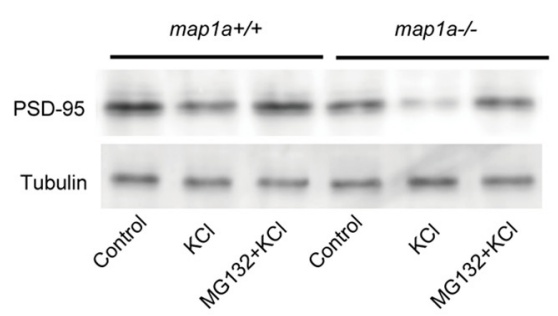

D

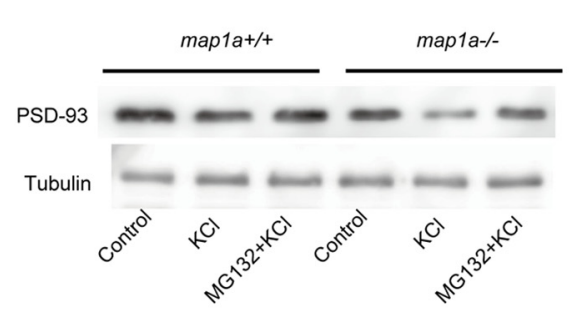

G

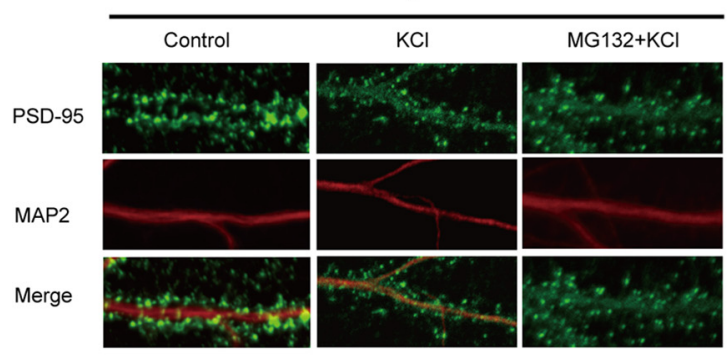

H

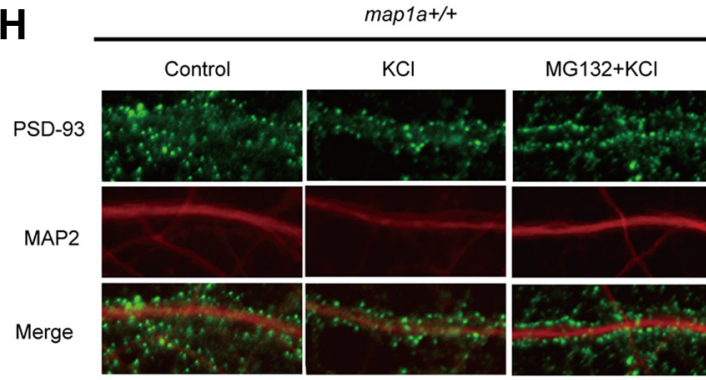

B

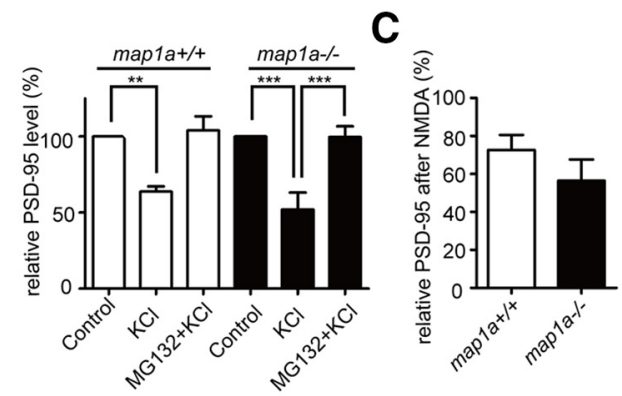

E

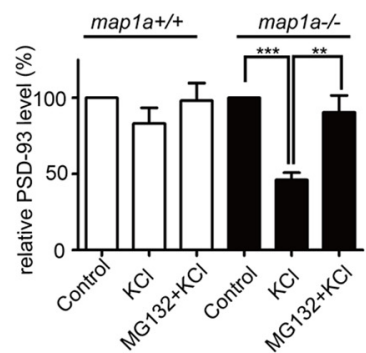

$\mathbf{F}$

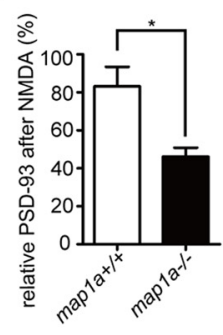

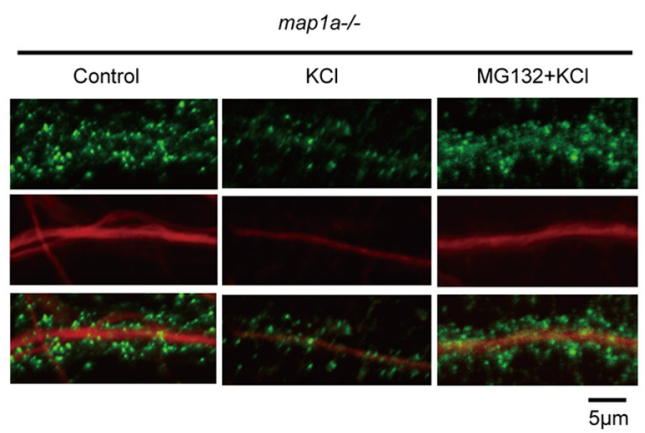
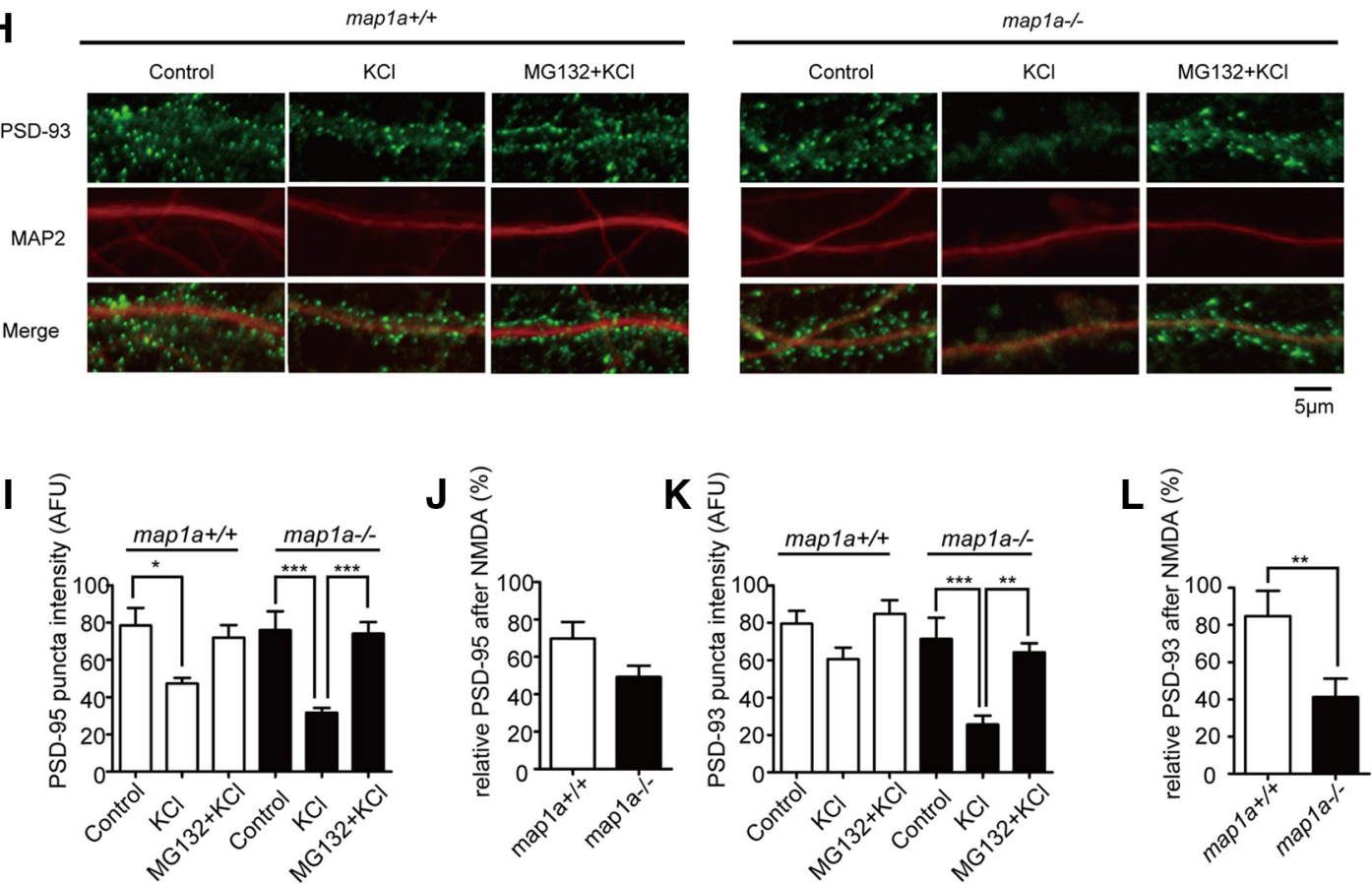

Figure 7. Enhanced activity-dependent degradation of PSD-93 in map $1 a^{-1-}$ mouse neurons. $A-F$, Western blot showed that high potassium treatment of cultured hippocampal neurons causes decreased PSD-95 (A-C) and PSD-93 (D-F) expression. $\boldsymbol{A}, \boldsymbol{D}$, Representative Western blots. $\boldsymbol{B}, \boldsymbol{E}$, Quantitative analysis of Western blots. $\boldsymbol{C}, \boldsymbol{F}$, After/before KCl treatment ratio of PSD-95 (C) or PSD-93 (D) expression. $\mathbf{G}-\mathbf{L}$, Immunostaining showed that high potassium treatment of cultured hippocampal neurons causes decreased PSD-95 $(\mathbf{G}, \boldsymbol{I}, \boldsymbol{J})$ and PSD-93 (H, $\boldsymbol{K}, \boldsymbol{L})$ expression. $\mathbf{G}, \boldsymbol{H}, \mathbf{R e p r e s e n t a t i v e}$ immunostaining images. $\boldsymbol{I}, \boldsymbol{K}$, Quantitative analysis of signal intensities of PSD-95 ( () and PSD-93 (K).J, $L$, After/before KCl treatment ratio of levels of PSD-95 (I) or PSD-93 (L) immunoreactivity per each cluster. ${ }^{*} p<0.05,{ }^{* *} p<0.01,{ }^{* * *} p<0.001$. 
A

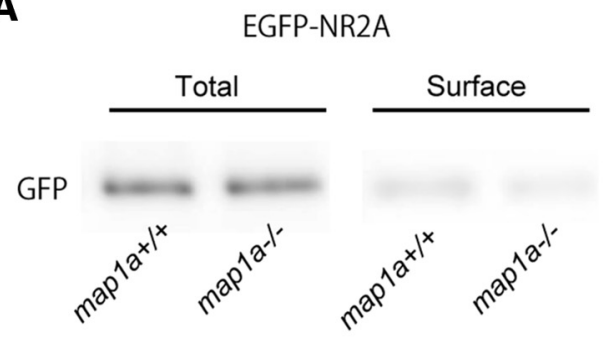

B

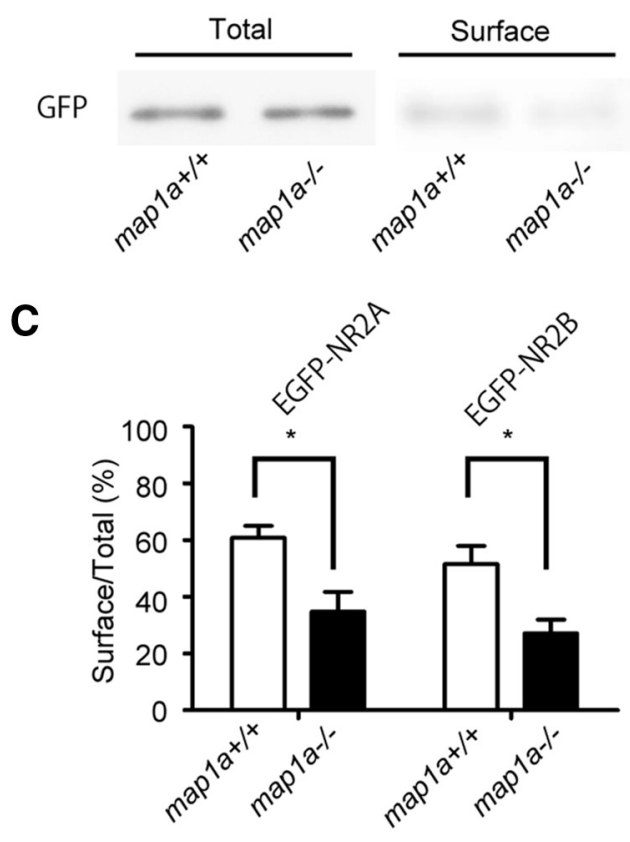

Figure 8. Surface expression of NR2A-EGFP and NR2B-EGFP vectors. $\boldsymbol{A}, \boldsymbol{B}$, Surface protein was labeled using the same method as experiments in Figure 3. The surface level of NR2A-EGFP $(\boldsymbol{A})$ and NR2B-EGFP $(\boldsymbol{B})$ was decreased markedly in map $1 a^{-1-}$ neurons. C, Percentage of surface/total proteins. Data (means \pm SEMs) were calculated from values obtained from five (NR2A-EGFP) and six (NR2B-EGFP) independent experiments. ${ }^{*} p<0.05$, two-tailed $t$ test.

calized EGFP signals, which enabled us to examine intracellular transport of EGFP-NR2A/2B using time-lapse recordings. We compared motility of EGFP-NR2A/2B clusters between mapla $a^{+/+}$and mapla ${ }^{-/-}$mouse neurons (Fig. 9A-D). Motility was categorized into four groups (stationary, vibrating, anterograde, and retrograde; Fig. 9C). In map $1 a^{-/-}$mouse neurons, the percentage of mobile clusters decreased especially in anterograde/retrograde categories compared with map $1 a^{+/+}$controls (Fig. 9A-C; EGFP-NR2A, 266-331 vesicles from 25-30 neurons of three to four mice were examined for each genotype, ${ }^{* *} p<$ 0.001 , independent $\chi^{2}$ test; EGFP-NR2B, 277-357 vesicles from 21-29 neurons of three mice were examined for each genotype, ${ }^{* *} p<0.001$, independent $\chi^{2}$ test). The mean velocity of EGFPNR2A/2B cluster movement in each category did not differ between genotypes (Fig. 9D; EGFP-NR2A, NS, 63-87 vesicles from 20-32 neurons of three to four mice were examined by ANOVA; EGFP-NR2B, NS, 55-86 vesicles from 15-21 neurons of three to four mice were examined by ANOVA). To study the significance of PSD-93 and PSD-95 in the transport of NR2A/2B, we performed knockdown experiments of PSD-93 or PSD-95. An miR vector was cotransfected with EGFP-NR2A or EGFP-NR2B vectors in primary hippocampal cultures (Fig. 9C,D). PSD-93 and
PSD-95 knockdown was assessed by Western blot analysis and immunocytochemistry, revealing that RNAi significantly inhibited expression of PSD-93 or PSD-95 (Fig. 9E,F). In PSD-93 knockdown neurons, the percentage of EGFP-NR2A/NR2B mobile clusters decreased, especially in anterograde/retrograde categories, compared with map $1 a^{+/+}$neurons (Fig. 9C). PSD-93 knockdown did not affect mean velocity of the cluster movement in each category (Fig. 9D). In contrast to the PSD-93 knockdown vector, PSD-95 knockdown did not significantly affect the percentage of EGFP-NR2A/NR2B mobile clusters (Fig. 9C) or the mean velocity of the cluster (Fig. 9D). For rescue experiments, cotransfection of RNAi-resistant PSD-93 with the PSD-93 RNAi vector was performed, which prevented changes in percentage of EGFP-NR2A/NR2B mobile clusters (Fig. 9C). Axonal vesicle transport visualized by synaptotagmin-yellow fluorescent protein (YFP) and dendritic transport of GABA receptor were not affected by MAP1A knock-out or PSD-93 knockdown (Nakajima et al., 2012; Fig. 9C,D; 256-282 vesicles from 25-30 neurons of three mice were examined for each value, NS, independent $\chi^{2}$ test), excluding the possibility that nonspecific changes in map $1 a^{-1-}$ or PSD-93 knockdown neurons caused altered dendritic transport of NR2A/2B. Together, these data suggest that microtubule-based transport of NR2A/2B-containing cargoes is dependent on MAP1A and PSD-93.

\section{Discussion}

The intracellular transport of glutamate receptors is a fundamental process for maintaining synaptic plasticity, with emerging evidence suggesting that the microtubule cytoskeleton plays an essential role in this process (Washbourne et al., 2002; Collingridge et al., 2004; Kneussel, 2005; Kennedy and Ehlers, 2006; Elias and Nicoll, 2007). Long-distance transport of neurotransmitter receptors and associated proteins is typically mediated by microtubule-based molecular motor complexes (Hirokawa et al., 2009). For example, KIF17, a member of the KIF family of molecular motors, is reported to transport NR2B-containing vesicles (Setou et al., 2000); however, it is not well understood how a variety of microtubule-related, as well as motor and non-motor, components is integrated to form the basis for NR transport.

Aside from molecular motors, another major category of microtubule-related proteins is the non-motor MAPs, such as MAP1A, MAP1B, MAP2, and tau (Hirokawa, 1994). As for the functional relationships of non-motor MAPs with organelle transport, a sufficient amount of evidence suggests that tau and MAP2 inhibit molecular motor-mediated vesicle/organelle transport (Seitz et al., 2002; Stamer et al., 2002). In striking contrast to the inhibitory effect of these MAPs, our data suggest that MAP1A has a different supportive role in organelle transport through binding with MAGUKs, such as PSD-93 (Brenman et al., 1996; Kim et al., 1996) and PSD-95 (Migaud et al., 1998). PSD-93 and PSD-95 are reported to bind to MAP1A through the MAGUK-binding (GK) domain (Brenman et al., 1998; Reese et al., 2007). Notably, the GK domain is not present in MAP1B but is unique to MAP1A (Noble et al., 1989; Brenman et al., 1998; Reese et al., 2007). Our data suggest that defects in NR2A/B transport in mapla $a^{-1-}$ mouse neurons is responsible for decreased synaptic localization of NR2A/2B. Then, how does MAP1A contribute to the maintenance of NR2A/2B transport? One possible explanation is that MAP1A provides an NR2A/2B anchor to cytoskeleton, and loss of the tethering could lead to decreased transport. Our data suggest a model of NR transport in dendrites (Fig. 10). In dendritic shafts, the NRs on microtubule tracks could take two different forms of protein complexes: "docked" and "mo- 
A

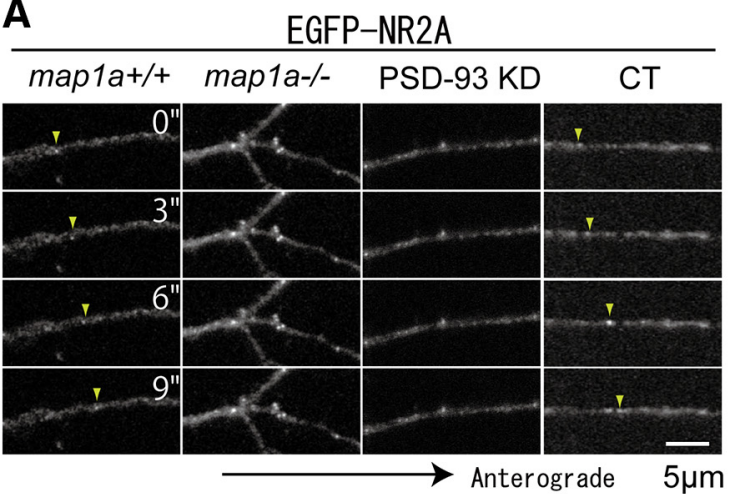

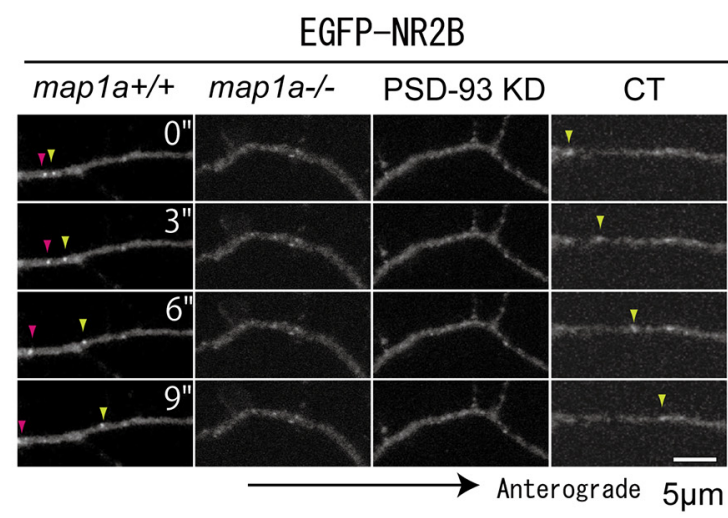

B
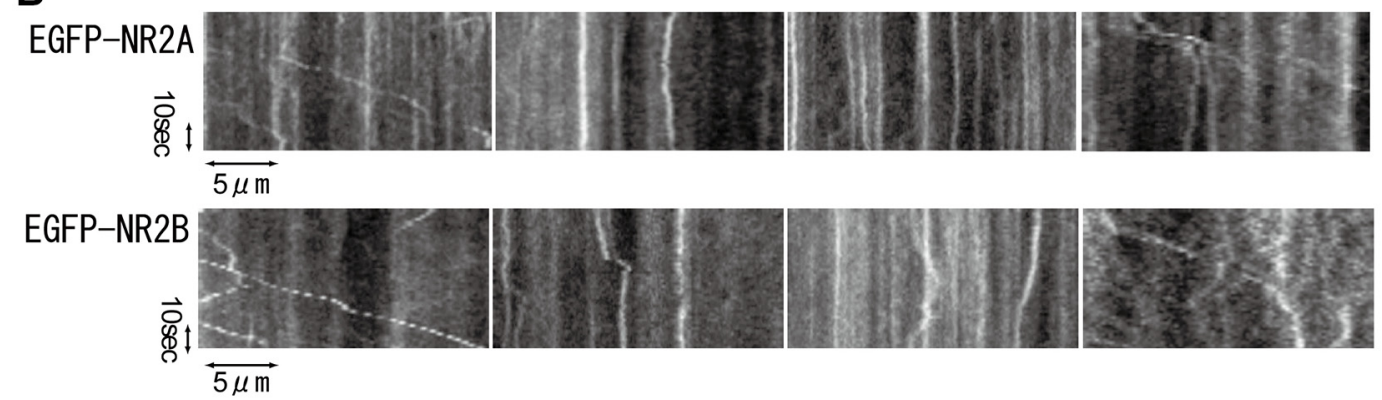

C
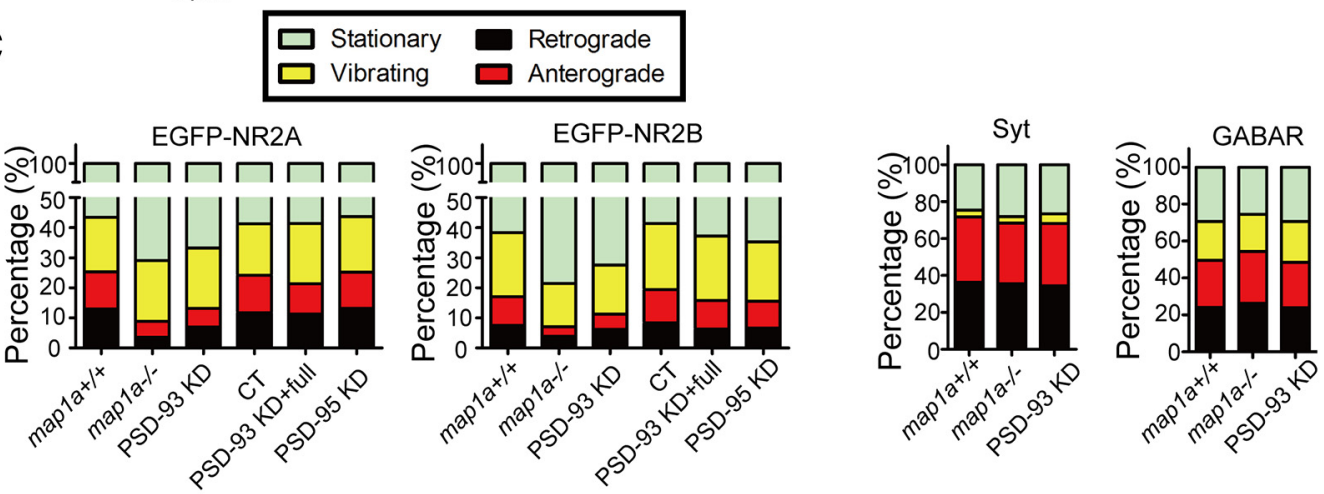

D

D EGFP-NR2A
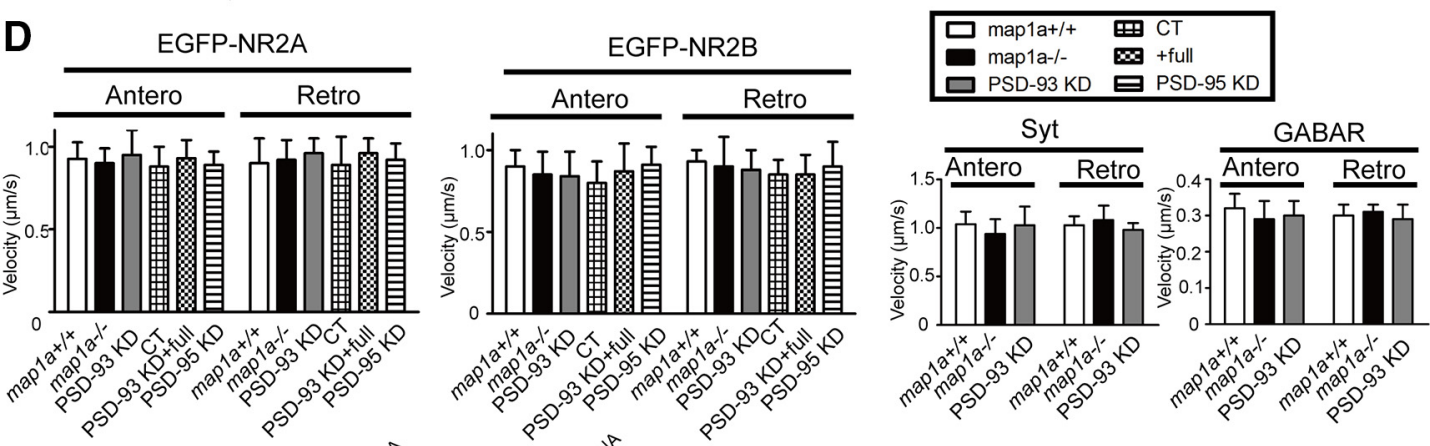

E

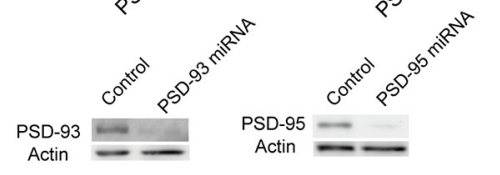

$\mathbf{F}$
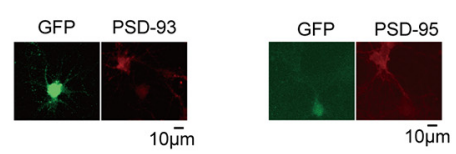

Figure 9. Reduced intracellular transport of EGFP-NR2A/2B in map1 ${ }^{-1-}$ mouse neurons. $\boldsymbol{A}, \boldsymbol{B}$, Time-lapse observation $(\boldsymbol{A})$ and kymograph $(\boldsymbol{B})$ of EGFP-NR2A/2B signals in the dendrites. PSD-93 KD, Wild-type neurons transfected with PSD-93-knockdown miR RNAi vector; CT, wild-type neurons transfected with mock miR RNAi for negative control. Neurons were treated with BPB, an extracellular GFP quenching reagent. Arrowheads indicate transported clusters. C, Classified vesicle motility of EGFP-NR2A, EGFP-NR2B, synaptotagmin-YFP, and GFP-GABA ${ }_{A}$ receptor. PSD-93 KD + full, Wild-type neurons cotransfected with PSD-93 knockdown miR RNAi vector and human PSD-93 expression vector; PSD-95 KD, wild-type neurons transfected with PSD-95-knockdown miR RNAi vector. D, Velocities for anterograde (Antero) and retrograde (Retro) movement of clusters. Means \pm SEMs are shown. $\boldsymbol{E}$, $\boldsymbol{F}$, Assessment of miR knockdown. $\boldsymbol{E}$, N1E-115 neuroblastoma cells were transfected with miRs against PSD-93 or PSD-95. Protein samples were recovered at $72 \mathrm{~h}$ after transfection and subjected to immunoblotting. Knockdown levels normalized to the levels of nontransfected cells; $23.4 \pm 5.1 \%$ (PSD-93 knockdown), $28.0 \pm 7.1 \%$ (PSD-95 knockdown), means \pm SEMs, values from five independent experiments. $\boldsymbol{F}$, Hippocampal neurons were cotransfected with miRs against PSD-93 or PSD-95 and an EGFP expression vector as an expression marker. At $72 \mathrm{~h}$ after transfection, neurons were fixed and stained with antibodies against PSD-93 and PSD-95. 
A

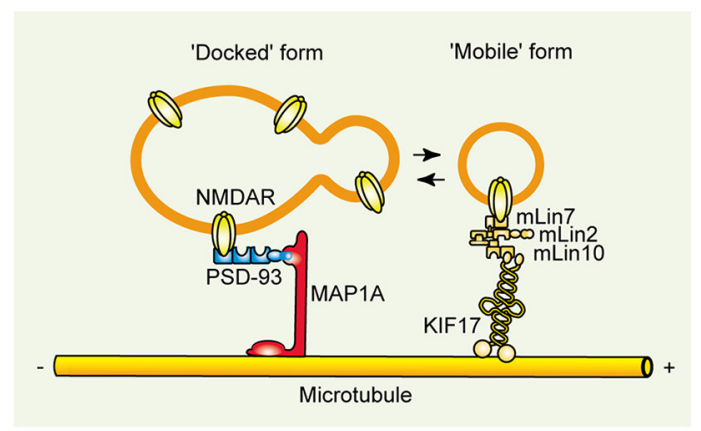

B map1a-/

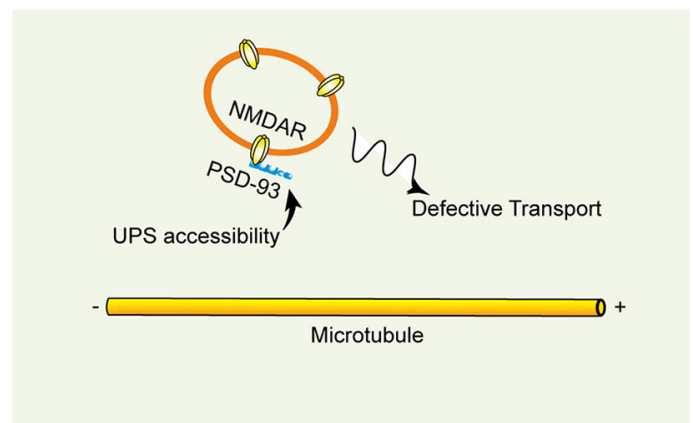

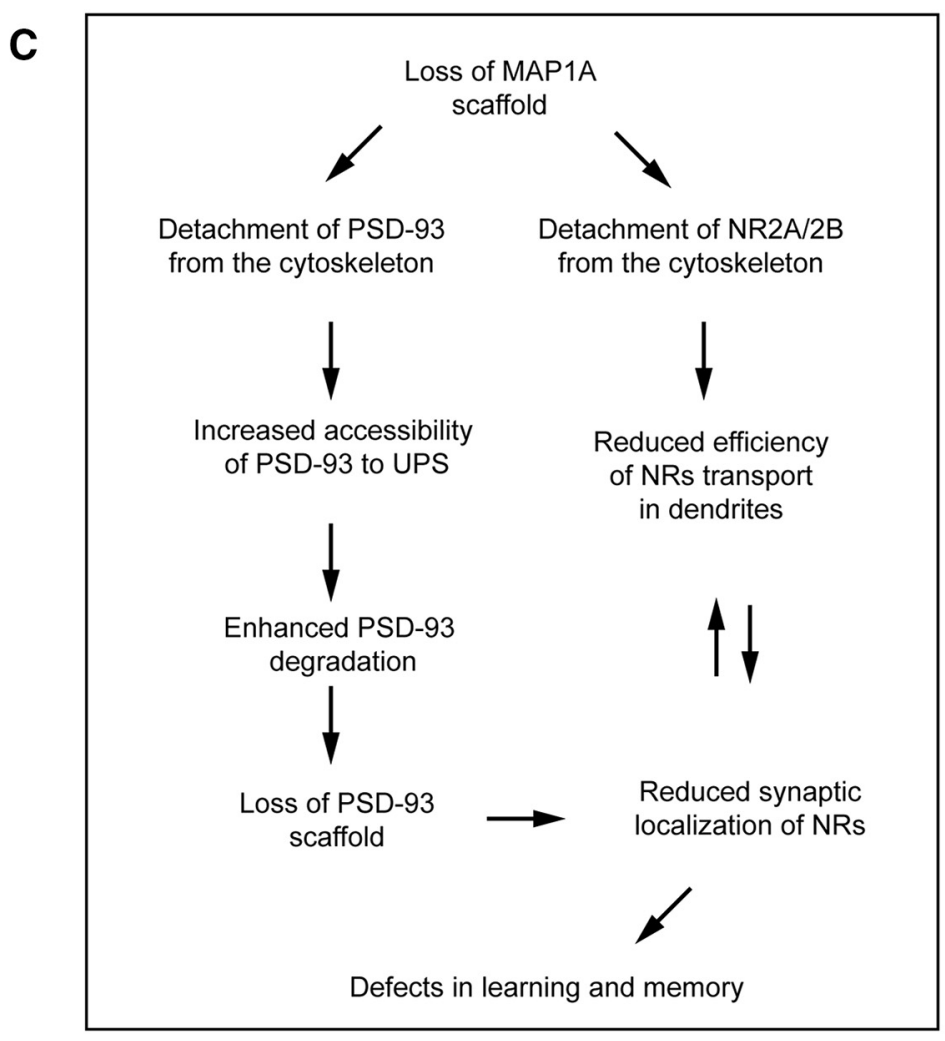

Figure 10. MAP1A supports NR transport and PSD-93 stability for synaptic plasticity. A, Docked and mobile form of NRs in wild-type dendrites. $\boldsymbol{B}$, Disrupted docked form of NRs in map 1a ${ }^{-/-}$ dendrites. $C$, Schematic of the molecular pathology predicted in $\operatorname{map} 1 a^{-/-}$mouse neurons.

bile." As reported previously, the mobile form contains the molecular motor KIF17, the mLin7/2/10 scaffolding complex, and the NR, as well as the transportation machinery (Setou et al., 2000). Conversely, the docked form is considered to contain PSD-93/95, which connects NRs to MAP1A on microtubules. It is speculated that the role of the docked form might be to maintain the location of NR-containing vesicles close to microtubule tracks and to support efficiency of NR trafficking via the mobile complex form (Fig. 10A). In dendrites, NRs detach easily from microtubules without the support of the docked form, resulting in a blockage of proper NR trafficking to synapses (Fig. 10B). Reduced NR levels in synapses could, in turn, affect the level of intracellular NR transport (Fig. 10C).

Another notable feature of neurons lacking MAP1A is the activity-dependent instability of PSD-93, which could also underlie defects in synaptic plasticity and NR2A/2B transport in MAP1A knock-out mouse neurons. PSD-95 is regulated by the ubiquitin-proteasome pathway (Colledge et al., 2003). Many other important synaptic molecules, such as Arc, are involved in the molecular mechanisms of activity-dependent synaptic plasticity under the regulation of ubiquitination and participate in postsynaptic function and plasticity (Mabb et al., 2014). Our results confirmed that PSD-95 is degraded in an activity-dependent manner and that degradation is blocked by the addition of a proteasomal inhibitor in the culture medium. PSD-93 also exhibited a similar decrease in response to high potassium stimulation (Fig. 5). This decrease was also blocked by a proteasomal inhibitor, showing that the level of PSD-93 is regulated by mechanisms similar to PSD-95. The activity-dependent decreases of PSD-93 levels were more enhanced in mapla $a^{-/-}$mouse neurons (Fig. 7). Then, why did the absence of MAP1A result in increased activitydependent PSD-93 degradation? Here, two possibilities could be considered. One is that association of MAP1A with PSD-93 obstructed accessibility of the ubiquitin-proteasome system (UPS), 
including ubiquitin ligases such as Mdm2 (Colledge et al., 2003). In that case, the lack of MAP1A in map $1 a^{-/-}$neurons should lead to an increased probability of contact between PSD-93 and UPS. The other is that detachment of PSD-93 from the cytoskeleton, caused by a loss of scaffolding by MAP1A, would lead to an increased probability of contact with UPS in the cytoplasm. Both mechanisms could contribute to increased PSD-93 degradation in mapla $1 a^{-1-}$ mouse neurons.

In summary, the lack of MAP1A resulted in two molecular events: (1) decreased NR2A/2B transport; and (2) increased activity-dependent UPS-mediated PSD-93 degradation. These two molecular mechanisms could synergistically contribute to memory disturbances observed in mapla $a^{-/-}$mice (Fig. 10C). Thus, our work suggests that MAP1A plays an essential role in synaptic plasticity through maintaining expression of PSD scaffolds and surface-expressed NR2A/2B, providing new insight into cytoskeleton-based supporting machinery for receptor transport.

\section{References}

Barria A, Malinow R (2002) Subunit-specific NMDA receptor trafficking to synapses. Neuron 35:345-353. CrossRef Medline

Brenman JE, Christopherson KS, Craven SE, McGee AW, Bredt DS (1996) Cloning and characterization of postsynaptic density 93 , a nitric oxide synthase interacting protein. J Neurosci 16:7407-7415. Medline

Brenman JE, Topinka JR, Cooper EC, McGee AW, Rosen J, Milroy T, Ralston HJ, Bredt DS (1998) Localization of postsynaptic density-93 to dendritic microtubules and interaction with microtubule-associated protein 1A. J Neurosci 18:8805-8813. Medline

Caceres A, Kosik KS (1990) Inhibition of neurite polarity by tau antisense oligonucleotides in primary cerebellar neurons. Nature 343:461-463. CrossRef Medline

Caceres A, Mautino J, Kosik KS (1992) Suppression of MAP2 in cultured cerebellar macroneurons inhibits minor neurite formation. Neuron 9:607-618. CrossRef Medline

Chien CL, Lu KS, Lin YS, Hsieh CJ, Hirokawa N (2005) The functional cooperation of MAP1A heavy chain and light chain 2 in the binding of microtubules. Exp Cell Res 308:446-458. CrossRef Medline

Colledge M, Snyder EM, Crozier RA, Soderling JA, Jin Y, Langeberg LK, Lu H, Bear MF, Scott JD (2003) Ubiquitination regulates PSD-95 degradation and AMPA receptor surface expression. Neuron 40:595-607. CrossRef Medline

Collingridge GL, Isaac JT, Wang YT (2004) Receptor trafficking and synaptic plasticity. Nat Rev Neurosci 5:952-962. CrossRef Medline

Collingridge GL, Peineau S, Howland JG, Wang YT (2010) Long-term depression in the CNS. Nat Rev Neurosci 11:459-473. CrossRef Medline

Cornea-Hébert V, Watkins KC, Roth BL, Kroeze WK, Gaudreau P, Leclerc N, Descarries L (2002) Similar ultrastructural distribution of the 5-HT(2A) serotonin receptor and microtubule-associated protein MAP1A in cortical dendrites of adult rat. Neuroscience 113:23-35. CrossRef Medline

Crawley JN (2000) What's wrong with my mouse? Behavioral phenotyping of transgenic and knockout mice, pp 95-99. New York: Wiley.

Edelmann W, Zervas M, Costello P, Roback L, Fischer I, Hammarback JA, Cowan N, Davies P, Wainer B, Kucherlapati R (1996) Neuronal abnormalities in microtubule-associated protein 1B mutant mice. Proc Natl Acad Sci U S A 93:1270-1275. CrossRef Medline

Elias GM, Nicoll RA (2007) Synaptic trafficking of glutamate receptors by MAGUK scaffolding proteins. Trends Cell Biol 17:343-352. CrossRef Medline

Fukaya M, Kato A, Lovett C, Tonegawa S, Watanabe M (2003) Retention of NMDA receptor NR2 subunits in the lumen of endoplasmic reticulum in targeted NR1 knockout mice. Proc Natl Acad Sci U S A 100:4855-4860. CrossRef Medline

Gong LW, De Camilli P (2008) Regulation of postsynaptic AMPA responses by synaptojanin 1. Proc Natl Acad Sci U S A 105:17561-17566. CrossRef Medline

González-Billault C, Demandt E, Wandosell F, Torres M, Bonaldo P, Stoykova A, Chowdhury K, Gruss P, Avila J, Sánchez MP (2000) Perinatal lethality of microtubule-associated protein 1B-deficient mice express- ing alternative isoforms of the protein at low levels. Mol Cell Neurosci 16:408-421. CrossRef Medline

Harada A, Oguchi K, Okabe S, Kuno J, Terada S, Ohshima T, Sato-Yoshitake R, Takei Y, Noda T, Hirokawa N (1994) Altered microtubule organization in small-calibre axons of mice lacking tau protein. Nature 369: 488-491. CrossRef Medline

Harada A, Teng J, Takei Y, Oguchi K, Hirokawa N (2002) MAP2 is required for dendrite elongation, PKA anchoring in dendrites, and proper PKA signal transduction. J Cell Biol 158:541-549. CrossRef Medline

Hirokawa N (1994) Microtubule organization and dynamics dependent on microtubule-associated proteins. Curr Opin Cell Biol 6:74-81. CrossRef Medline

Hirokawa N, Noda Y, Tanaka Y, Niwa S (2009) Kinesin superfamily motor proteins and intracellular transport. Nat Rev Mol Cell Biol 10:682-696. CrossRef Medline

Ikeda A, Zheng QY, Zuberi AR, Johnson KR, Naggert JK, Nishina PM (2002) Microtubule-associated protein $1 \mathrm{~A}$ is a modifier of tubby hearing (moth1). Nat Genet 30:401-405. CrossRef Medline

Kennedy MJ, Ehlers MD (2006) Organelles and trafficking machinery for postsynaptic plasticity. Annu Rev Neurosci 29:325-362. CrossRef Medline

Kim E, Sheng M (2004) PDZ domain proteins of synapses. Nat Rev Neurosci 5:771-781. CrossRef Medline

Kim E, Cho KO, Rothschild A, Sheng M (1996) Heteromultimerization and NMDA receptor-clustering activity of Chapsyn-110, a member of the PSD-95 family of proteins. Neuron 17:103-113. CrossRef Medline

Kneussel M (2005) Postsynaptic scaffold proteins at non-synaptic sites. The role of postsynaptic scaffold proteins in motor-protein-receptor complexes. EMBO Rep 6:22-27. CrossRef Medline

LeDoux JE (2000) Emotion circuits in the brain. Annu Rev Neurosci 23: 155-184. CrossRef Medline

Mabb AM, Je HS, Wall MJ, Robinson CG, Larsen RS, Qiang Y, Corrêa SA, Ehlers MD (2014) Triad3A regulates synaptic strength by ubiquitination of Arc. Neuron 82:1299-1316. CrossRef Medline

Malenka RC, Nicoll RA (1999) Long-term potentiation: a decade of progress? Science 285:1870-1874. CrossRef Medline

Meixner A, Haverkamp S, Wässle H, Führer S, Thalhammer J, Kropf N, Bittner RE, Lassmann H, Wiche G, Propst F (2000) MAP1B is required for axon guidance and is involved in the development of the central and peripheral nervous system. J Cell Biol 151:1169-1178. CrossRef Medline

Migaud M, Charlesworth P, Dempster M, Webster LC, Watabe AM, Makhinson M, He Y, Ramsay MF, Morris RG, Morrison JH, O’Dell TJ, Grant SG (1998) Enhanced long-term potentiation and impaired learning in mice with mutant postsynaptic density-95 protein. Nature 396:433-439. CrossRef Medline

Morris RG (1989) Synaptic plasticity and learning: selective impairment of learning in rats and blockade of long-term potentiation in vivo by the $N$-methyl-D-aspartate receptor antagonist AP-5. J Neurosci 9:3040-3057. Medline

Nakajima K, Yin X, Takei Y, Seog DH, Homma N, Hirokawa N (2012) Molecular motor KIF5A is essential for GABA(A) receptor transport, and KIF5A deletion causes epilepsy. Neuron 76:945-961. CrossRef Medline

Noble M, Lewis SA, Cowan NJ (1989) The microtubule binding domain of microtubule-associated protein MAP1B contains a repeated sequence motif unrelated to that of MAP2 and tau. J Cell Biol 109:3367-3376. CrossRef Medline

Reese ML, Dakoji S, Bredt DS, Dötsch V (2007) The guanylate kinase domain of the MAGUK PSD-95 binds dynamically to a conserved motif in MAP1a. Nat Struct Mol Biol 14:155-163. CrossRef Medline

Sakimura K, Kutsuwada T, Ito I, Manabe T, Takayama C, Kushiya E, Yagi T, Aizawa S, Inoue Y, Sugiyama H (1995) Reduced hippocampal LTP and spatial learning in mice lacking NMDA receptor epsilon 1 subunit. Nature 373:151-155. CrossRef Medline

Sato-Yoshitake R, Shiomura Y, Miyasaka H, Hirokawa N (1989) Microtubule-associated protein 1B: molecular structure, localization, and phosphorylation-dependent expression in developing neurons. Neuron 3:229-238. CrossRef Medline

Schoenfeld TA, McKerracher L, Obar R, Vallee RB (1989) MAP1A and MAP1B are structurally related microtubule associated proteins with distinct developmental patterns in the CNS. J Neurosci 9:1712-1730. Medline

Seitz A, Kojima H, Oiwa K, Mandelkow EM, Song YH, Mandelkow E (2002) 
Single-molecule investigation of the interference between kinesin, tau and MAP2c. EMBO J 21:4896-4905. CrossRef Medline

Setou M, Nakagawa T, Seog DH, Hirokawa N (2000) Kinesin superfamily motor protein KIF17 and mLin-10 in NMDA receptor-containing vesicle transport. Science 288:1796-1802. CrossRef Medline

Shiomura Y, Hirokawa N (1987a) The molecular structure of microtubuleassociated protein 1A (MAP1A) in vivo and in vitro. An immunoelectron microscopy and quick-freeze, deep-etch study. J Neurosci 7:1461-1469. Medline

Shiomura Y, Hirokawa N (1987b) Colocalization of microtubuleassociated protein $1 \mathrm{~A}$ and microtubule-associated protein 2 on neuronal microtubules in situ revealed with double-label immunoelectron microscopy. J Cell Biol 104:1575-1578. CrossRef Medline

Song AH, Wang D, Chen G, Li Y, Luo J, Duan S, Poo MM (2009) A selective filter for cytoplasmic transport at the axon initial segment. Cell 136: 1148-1160. CrossRef Medline

Stamer K, Vogel R, Thies E, Mandelkow E, Mandelkow EM (2002) Tau blocks traffic of organelles, neurofilaments, and APP vesicles in neurons and enhances oxidative stress. J Cell Biol 156:1051-1063. CrossRef Medline

Szebenyi G, Bollati F, Bisbal M, Sheridan S, Faas L, Wray R, Haferkamp S, Nguyen S, Caceres A, Brady ST (2005) Activity-dependent dendritic remodeling requires microtubule-associated protein 1A. Curr Biol 15: 1820-1826. CrossRef Medline

Takei Y, Harada A, Takeda S, Kobayashi K, Terada S, Noda T, Takahashi T, Hirokawa N (1995) Synapsin I deficiency results in the structural change in the presynaptic terminals in the murine nervous system. J Cell Biol 131:1789-1800. CrossRef Medline

Takei Y, Teng J, Harada A, Hirokawa N (2000) Defects in axonal elongation and neuronal migration in mice with disrupted tau and map $1 b$ genes. J Cell Biol 150:989-1000. CrossRef Medline

Tang YP, Shimizu E, Dube GR, Rampon C, Kerchner GA, Zhuo M, Liu G, Tsien JZ (1999) Genetic enhancement of learning and memory in mice. Nature 401:63-69. CrossRef Medline

Tao YX, Rumbaugh G, Wang GD, Petralia RS, Zhao C, Kauer FW, Tao F, Zhuo M, Wenthold RJ, Raja SN, Huganir RL, Bredt DS, Johns RA (2003) Impaired NMDA receptor-mediated postsynaptic function and blunted NMDA receptor-dependent persistent pain in mice lacking postsynaptic density-93 protein. J Neurosci 23:6703-6712. Medline

Tsien JZ, Huerta PT, Tonegawa S (1996) The essential role of hipocampal CA1 NMDA receptor-dependent synaptic plasticity in spatial memory. Cell 87:1327-1338. CrossRef Medline

Tucker RP, Garner CC, Matus A (1989) In situ localization of microtubuleassociated protein mRNA in the developing and adult rat brain. Neuron 2:1245-1256. CrossRef Medline

Washbourne P, Bennett JE, McAllister AK (2002) Rapid recruitment of NMDA receptor transport packets to nascent synapses. Nat Neurosci 5:751-759. Medline

Yin X, Takei Y, Kido MA, Hirokawa N (2011) Molecular motor KIF17 is fundamental for memory and learning via differential support of synaptic NR2A/2B levels. Neuron 70:310-325. CrossRef Medline 